Gençkaya, Ö. F., Gündoğdu, H. G. ve Aytekin, A. (2021). "Büyükşehir Belediyeleri Web Sitelerinin Yönetişim ilkeleri Açısından Değerlendirilmesi”, Eskişehir Osmangazi Üniversitesi iïBF Dergisi, 16(3), 705 - 726.

Doi: 10.17153/oguiibf.935192

Başvuru: 09.05.2021 Kabul: 13.08.2021

Araştırma Makalesi/Research Article

\title{
Büyükşehir Belediyeleri Web Sitelerinin Yönetişim Illkeleri Açısından Değerlendirilmesi
}

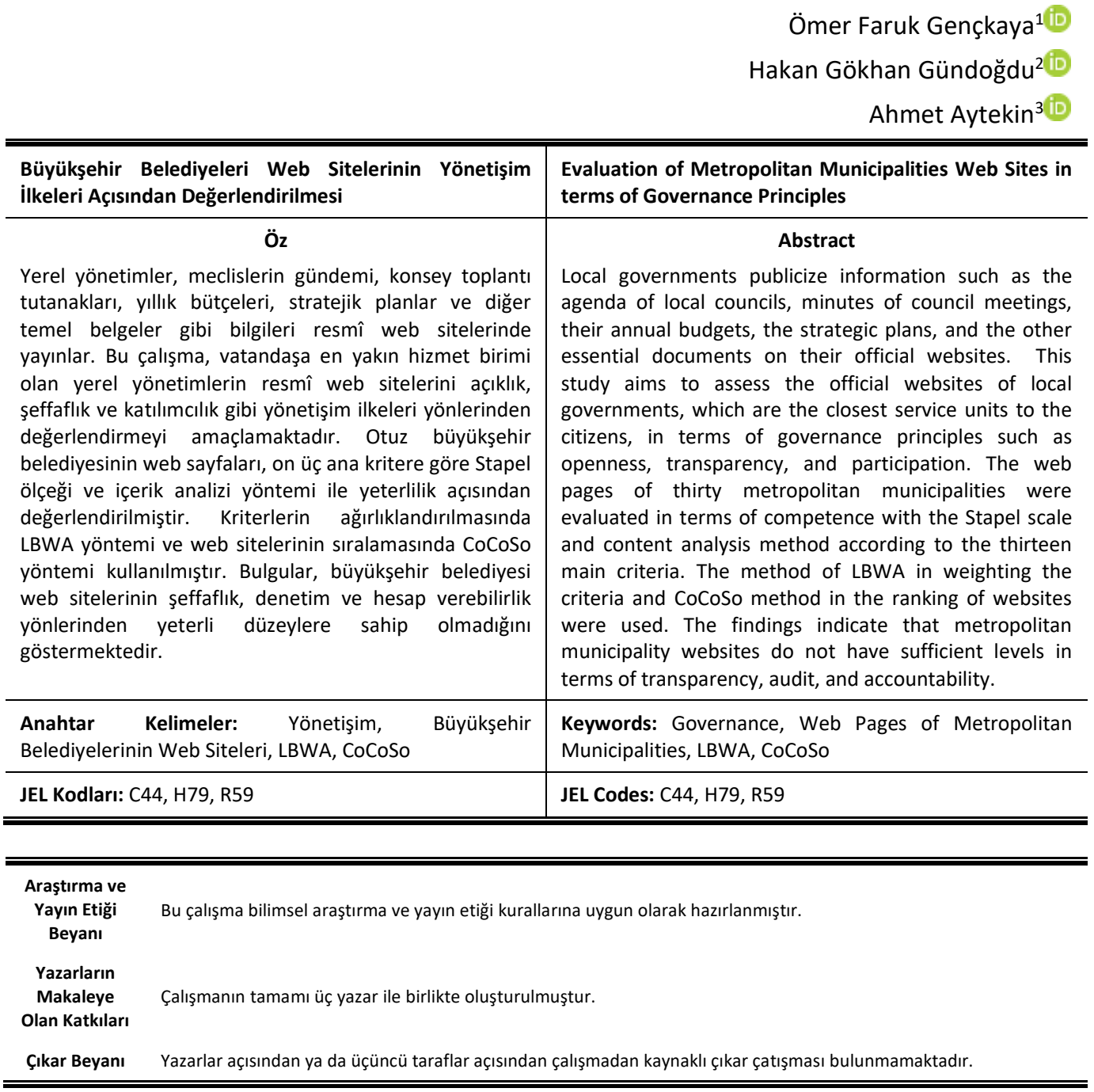

\footnotetext{
1 Prof. Dr., Marmara Üniversitesi, Siyasal Bilgiler Fakültesi, Siyaset Bilimi ve Kamu Yönetimi Bölümü, faruk.genckaya@marmara.edu.tr

2 Arş. Gör. Dr., Anadolu Üniversitesi, İktisat Fakültesi, Siyaset Bilimi ve Kamu Yönetimi Bölümü, hakanggundogdu@anadolu.edu.tr

3 Arş. Gör. Dr., Artvin Çoruh Üniversitesi, Hopa İktisadi ve İdari Bilimler Fakültesi, İşletme Bölümü, ahmetaytekin@artvin.edu.tr
} 


\section{Giriş}

Bilişim ve iletişim teknolojilerinin (Вї) sağladığı kolaylıklar, 1990'lardan bu yana öncelikle merkezi yönetimden başlayarak tüm kamu kurumlarında dijitalleşmeyi yaygınlaştırdı. Yapay zekâ, "nesnelerin interneti" (IOT) ve "blok zinciri" (blockchain) gibi teknolojideki gelişmelerin etkisiyle yönetsel süreçlerde e-devlet uygulamaları arttı. Sosyal medyanın kitleler tarafından alternatif bir iletişim kaynağı olması, "Büyük Veri" (Big Data) teknolojisine etkin bir katkı sağlarken, kamusal karar alma süreçlerinde vatandaş katılımı paradigması büyük değişikliklere uğradı (Liu ve Yuan, 2015). Bu gelişmeler ekonomik, siyasal ve toplumsal-kültürel değişimle birlikte kent yönetimlerinde "Akıllı Kent" (Smart City) gibi uygulamaların benimsenmesine neden oldu (Cocchia, 2014). Özellikle, farklı düzlemlerdeki kamu yönetimlerinin bilgilerini en yaygın bir biçimde internet üzerinden paylaşmaları (Piotrowski ve Borry, 2009) yönetim ve yönetilenler arasındaki iletişimi artırdı (Boulianne, 2009). Öte yandan, yönetim sürecinde şeffaflığın artması ile yolsuzluk ve benzeri eylemler azalmaya başlamış ve halkın yönetime güveni de artmıştır (Lupu ve Lazăr, 2015; Bertot vd., 2012).

"Hizmette yerellik" (subsidiarity) ilkesi ve Avrupa Yerel Yönetimler Özerklik Şartı (Madde 4/3) bağlamında, halka en yakın yönetim birimleri olan belediyeler hizmetlerinde şeffaflık ve hesap verebilirlik ilkelerini ve katılımı teşvik ederek yerel demokrasinin ve yönetişimin gelişmesine olanak sağlamaktadır (Keleş, 2019). Son yıllarda, belediyelerin web siteleri üzerinden yerel yönetimlerin dijital yönetişim (Holzer ve Manoharan, 2016) ve şeffafık düzeylerini (Holzer ve Kim, 2005; da Cruz vd., 2016; Holzer ve Manoharan, 2016; NavarroHeras vd., 2016; Garrido-Rodríguez vd., 2019; Kosova Democratic Institute ve NGO AKTIV, 2020) ölçmek üzere yerel yönetimlere özgü endeksler geliştirilmiştir. Türkiye'de belediyelerin web sitelerinin genellikle işlevsellikleri konusunda çeşitli çalışmalar yapılmış; ayrıca, İstanbul'da 37 ilçe belediyesinin web sitelerinde iyi yönetişim ilkelerinin uygulama düzeylerini değerlendiren, bir "belediye yönetişim karnesi" hazırlanmıştır (Argüden vd., 2018).

Bu çalışma, Türkiye'deki 30 büyükşehir belediyesinin kurumsal web sitelerinin iyi yönetişimin şeffaflık ilkesine ne ölçüde uygun olduklarının değerlendirilmesini amaçlamaktadır. Bu kapsamda, yönetimde şeffaflı̆ın boyutları ve bunların hesap verebilirliğe olası etkileri erişilebilirlik, güvenilirlik ve süreklilik bakımından incelenecektir. Çalışmanın temel araştırma sorusu, büyükşehir belediyeleri web sitelerinin yerel yönetimlerde şeffaflığı teşvik etme potansiyellerinin ne düzeyde olduğudur? Diğer bir ifadeyle, bu çalışma mevcut büyükşehir belediyeleri web sitelerinin şeffaflık bağlamında yönetişim kriterlerini ne oranda karşıladıklarını değerlendirecektir.

Aşağıda ilk olarak, açıklık, şeffaflık ve hesap verebilirlik kavramları ile ilgili yazın incelemesinden sonra Türk kamu yönetiminde şeffaflık ilkesi ile ilgili mevcut düzenlemeler anlatılacaktır. Daha sonra, büyükşehir belediyelerinin web siteleri yönetişim kriterlerine göre ve çok kriterli karar verme yöntemleri kullanılarak çözümlenecektir. Son olarak, araştırma bulguları ışı̆ında genel bir değerlendirme yapılacaktır. 


\section{Belediyelerin Web Sitelerinde Açıklık, Şeffaflık ve Hesap Verebilirlik}

Yönetim süreçlerinde BiT'lerin daha etkin bir biçimde kullanmasıyla birlikte (Moon, 2002; Quinn, 2003; Welch vd., 2005; Cullier ve Piotrowski, 2009; Bertot vd., 2012), bilgiye erişim olanaklarının artması (Roberts, 2006; Piotrowski ve Van Ryzin, 2007; Jaeger ve Bertot, 2010; Lindquist ve Huse, 2017) yönetimde şeffaflık anlayışını da geliştirmiştir (Moon, 2003; Andersen vd., 2010; Ruano de La Fuente, 2014). Demokratik toplumun ön koşullarından olan açıklık ve şeffaflık (Birkinshaw, 2006, Hirsch ve Osborne, 2000) ile hesap verebilirlik anlayışına bağlı olarak "iyi yönetişim" temelli uygulamalar öne çıkmaktadır (Tasan-Kok ve Vranken, 2011; Gündoğdu, 2020). Yönetsel süreçlerde BiT’lerin yaygınlaşmasının vatandaşın yönetsel verilere ulaşmasını kolaylaştırdığı; şeffaflığın dürüstlük (bütünlük) ve hesap verebilirliğin ön koşulu olduğu (Transparency International, 2015) ve yolsuzluğu azaltarak (Stasavage, 2003) yönetime güveni güçlendirdiği vurgulanmaktadır (Pina vd., 2007). E-devlet konulu çalışmalarda genellikle şeffaflığın yönetsel verimlilik ve etkililik üzerindeki etkileri incelenmektedir (Arslan, 2012; Mecek, 2017; Twizeyimana ve Andersson, 2019; Şahin, 2019). Şeffaflıkla ilgili bilimsel çalışmaların merkezi yönetime (Heald, 2003; Armstrong, 2011; Harrison ve Sayogo, 2014) ya da büyük şehirlere (Piotrowski ve Borry; 2009; Ruano de La Fuente, 2014; da Cruz vd., 2016) odaklandığı görülmektedir.

Türkiye'de belediyelerin e-belediye uygulamaları ve web sitelerine yönelik çalışmalar üç ana grupta toplanmaktadır (Mecek, 2017): içeriğin işlevselliği, kullanıcıların memnuniyeti ve donanım-teknik altyapı olanakları. Bu çalışmalar büyükşehir, il ve ilçe belediyelerini kapsamaktadır. Bununla birlikte, belediyelerin web sitelerinin kullanımı ile ilgili çalışmalar konu itibariyle farklılık göstermektedir. Söz konusu çalışmalar genel olarak kıyaslama yoluyla (Eraslan-Yayınoğlu vd., 2007), işlevselliğe göre (Parlak ve Sobacı, 2008; Aktel, 2009; Kerman vd., 2012; Alat, 2018), e-katılım uygulamalarına göre (Sobacı ve Altınok, 2011; Şat, 2016), mobil devlet hizmetlerine göre (Arslan, 2012), e-belediyecilik hizmetlerine göre (Tosun, 2008; Alodalı vd., 2012, Şat, 2016, Sayımer vd., 2019), kamusal değer yaklaşımına göre (Karkin ve Jansen, 2014) ve bilgi edinme hakkına göre (Emini ve Ayaz, 2018) değerlendirilmiştir. Ayrıca, konuyla ilgili yapılan yayınların genel kapsamlarıyla irdelendiği bir çalışmada bulunmaktadır (Mecek, 2017).

Türkiye'de farklı ölçeklerdeki belediyelerin web sitelerinin içeriği, işlevselliği ve kullanımı konusunda az sayıda bilimsel yayında katılımcılık ve etkileşimli uygulamaların yeterli düzeyde olmadığı belirtilirken (Yıldız, 1999; T.C. Sayıştay, 2006; Eraslan-Yayınoğlu vd., 2007; Tosun, 2008; Alodalı vd., 2012; Arslan, 2012; Kerman vd., 2012; Negiz ve Saraçbaşı, 2012; Mecek, 2017; Sayımer vd., 2019), şeffaflık konusunda farklı değerlendirmeler yapılmaktadır (Parlak ve Sobacı, 2008; Aktel, 2009; Kerman vd. 2012; Karkin ve Janssen, 2014; Şat, 2016; Mecek, 2017; Alat, 2018; Emini ve Ayaz, 2018; Sayımer vd., 2019).

Türkiye'de yönetişim odaklı reform çalışmalarında kamu yönetiminin nitelikleri arasında şeffaflık ve hesap verebilirlik vurgulanmıştır (T.C. Başbakanlık, 2003). 2003'te yürürlüğe giren 5018 sayılı Kamu Mali Yönetimi ve Kontrol Kanunu'nda 2006'da yapılan değişiklikle kamu kurumlarında yönetişim ilkelerinin uygulanması öngörülmüştür. Bu bağlamda, büyükşehir belediyelerinin kamu kaynaklarını etkin ve verimli kullanması, kurumsal web sitelerinde stratejik plan, program ve raporların bulunması, açıklık ve şeffaflık ilkelerinin dikkate alınmasını sağlamıştır. Aynı zamanda katılımcılığı da artırmak üzere, 2003/12 Sayılı Başbakanlık Genelgesi BiT kullanımının yaygınlaştırılmasına yönelik olarak bir "e-Dönüşüm Türkiye Projesi" uygulamaya konulmuştur. Anayasa'da (Madde 31/son) bilgi edinme hakkı 
kabul edilmiş ve 4982 sayılı Bilgi Edinme Kanunu 2004'te yürürlüğe girmiştir. Ayrıca, 2004'te yürürlüğe giren 5176 sayılı Kamu Görevlileri Etik Kurulu Kurulması Hakkındaki Kanun ve izleyen yıl yayımlanan Kamu Görevlileri Etik Davranış İlkeleri ile Başvuru Usul ve Esasları Hakkındaki Yönetmelik ile kamu kurumlarında belediyeler dâhil olmak üzere etik komisyonların oluşturulması zorunlu kılınmıştır.

Yerel yönetimler reformu çerçevesinde 2005'te kabul edilen 5393 sayılı Belediye Kanunu (Madde 13) hemşerilerin, belediye karar ve hizmetlerine katılma, belediye faaliyetleri hakkında bilgilenme haklarını (Madde 14) ve 5216 sayılı Büyükşehir Belediyesi Kanunu (Madde 7) belediyenin görevleri arasında coğrafi ve kent bilgi sistemleri yapmak ya da yaptırmayı saymıştır. Ayrıca, 5216 sayılı Büyükşehir Belediyesi Kanunu (Madde 8) kamu kurum ve kuruluşlarıyla özel kuruluşların alt yapı koordinasyon merkezinin isteyeceği coğrafi bilgi sistemleri dâhil her türlü bilgi ve belgeyi vermek zorunda olduğunu belirtmektedir.

5393 sayılı Belediye Kanunu'ndaki açıklık, şeffaflık ve hesap verebilirlik ile ilgili hükümler aşağıda belirtilmiştir:

- Belediye meclis gündemi... çeşitli yöntemlerle halka duyurulur (Madde 21);

- Kesinleşen meclis kararlarının özetleri yedi gün içinde uygun araçlarla halka duyurulur (Madde 23/son);

- (Ihtisas) Komisyon raporları alenîdir, çeşitli yollarla halka duyurulur ve isteyenlere meclis tarafından maliyetlerini aşmamak üzere belirlenecek bedel karşıı̆ı̆nda verilir (Madde 24/son).

5018 sayılı Kanun'a uygun olarak mali ve performans denetimi kapsamında "iç" ve "dış" denetimin gerçekleşmesi, yıllık performans programının hazırlanması, faaliyet raporlarının oluşturulması ve tüm bunların açıklık ve şeffaflık ilkeleri gereğince belediye meclisi ve kamuoyu ile paylaşılması gerekmektedir (Maddeler 54, 55/son ve 56/2).

Belediye Kanunu'nda (Madde 76) demokratik yönetişim bağlamında paydaş yaklaşımıyla oluşturulan kent konseylerinin kurulması 2006'da İçişleri Bakanlığınca hazırlanan "Kent Konseylerinin Kurulmasına İlişkin Yönetmelik" çerçevesinde uygulanmaktadır.

Belediyeler dâhil tüm merkezi ve yerinden yönetim kurum ve kuruluşları kapsayacak bir biçimde 2006'da 2006/10316 sayılı Bakanlar Kurulu Kararı ve 10.8.2006 tarihli ve 2006/22 sayılı Başbakanlık Genelgesi ile vatandaşların açık veri anlayışı doğrultusunda bilgi edinme ve uzaktan kamu hizmetlerine erişim sağlamalarına yönelik olarak E-Devlet Kapısının kurulması kararlaştırılmış ve söz konusu portal 2008'de tamamlanmıştır. Konuyla ilgili tamamlayıcı mevzuat, 2004'te yürürlüğe giren 5070 sayılı Elektronik İmza Kanunu ve yerel yönetim birimlerinin Kamu İnternet Erişim Merkezlerinin yaygınlaştırılmasına yönelik 2005'te yürürlüğe giren ve 5369 sayılı Evrensel Hizmet Kanunu'dur.

Türkiye, son yıllarda e-devlet gelişme endekslerinde alt yapı konusunda yavaş ilerleme sağlamakla birlikte insan kaynakları ve e-hizmetler alanlarında hızlı bir ilerleme sağlamaktadır. Eldeki son verilere göre, Türkiye e-devlet araştırmasında (UN, 2020) 139 ülke arasında 53., dijital-devlet endeksinde (Obi, 2018) 65 devlet arasında 41. sırada yer alırken, Avrupa Birliği edevlet ölçümleme çalışmasında (European Commission, 2020) bazı eksikliklere karşın genellikle $A B$ ortalamasına yakın bir yerde bulunmaktadır (Genç, 2019).

Kamu yönetiminde web sitelerinin sayısı son yıllarda genel olarak artarken belediyelerin de içerisinde bulunduğu diğer kamu kuruluşlarında (silahlı kuvvetler ve polis) sayının göreli olarak azaldığı görülmektedir (T.C. Kalkınma Bakanlığı, 2018). 2018'de 5393 sayılı Kanun'a eklenen 
bir madde (Ek Madde 3) ile Türkiye'de dijital dönüşümün yerel ayağı olarak belediyelerin kendilerine verilen görev ve hizmetlere ilişkin her türlü idari iş ve işlemi yürütmek üzere, standartları İçişleri ve Çevre ve Şehircilik Bakanlıkları tarafından geliştirilecek e-belediye sistemini kullanmaları düzenlenmiştir. Belediyelerin mobil hizmet (m-belediye) uygulamalarının artmasının yanında, 2021 Mart ayı itibariyle (turkiye.gov.tr) e-Devlet Kapısı ile 80 ilde bulunan 361 belediyenin yanı sıra, belediyelere bağlı 25 adet yerel hizmet kurumunun E-devlet kapısı üzerinden sağlanması, kurumsal yeniden örgütlenmeler, mali ve donanımsal sınırlamaların bu konuda etkili olduğu düşünülmektedir.

\section{Araştırmanın Yöntemi}

Yerel yönetim birimleri arasında büyükşehir belediyeleri maddi kaynak, donanım, kamu hizmeti sunumu ve katılım yönünden önemli bir konumda bulunmaktadır (Gündoğdu, 2018). $\mathrm{Bu}$ kapsamda çalışmada, büyükşehir belediyeleri web siteleri açıklık, şeffaflık ve hesap verebilirlik gibi yönetişim kriterlerinden oluşturulan bir ölçeğe göre değerlendirilecektir. Bu çalışmada şeffaflık kavramı "tüm yönetsel temsilcilerle ve eylemlerle ilgili bilgilerin sivil topluma eksiksiz, zamanında ve erişilebilir bir biçimde çevrimiçi sunulması" (da Cruz vd., 2016) olarak tanımlanmaktadır. Araştırmanın kapsamındaki, 30 büyükşehir belediyesi ülke nüfusunun \%78 ve yüz ölçümünün \%51'ini oluşturmakta; 2014-2017 döneminde yerel yönetimler bütçe giderlerinin ortalama $\% 80^{\prime}$ i ve GSYiH olarak $\% 3,5^{\prime}$ i büyükşehir belediyeleri tarafından sağlanmaktadır (Uzunali ve Görmez, 2019).

Çalışmada, büyükşehir belediyelerinin yönetişim kriterlerine göre değerlendirilmesinde Stapel ölçeği, kriterlerin ağırlıklandırılmasında LBWA (Seviye Temelli Ağırlık Değerlendirme; Level Based Weight Assessment) ve belediyelerin sıralanmasında ise CoCoSo (Birleştirilmiş Uzlaşık Çözüm; Combined Compromise Solution) yönteminden yararlanılmıştır. Stapel Ölçeği, adını geliştiricisi Jan Stapel'den almıştır ve tek bir ifadenin orta dereceye yerleştirilmesi ile ölçeklendirme işlemi sağlamaktadır. Ölçeğin ortasında bulunan ifadeye katılım düzeyi, bu ifadenin altında ve üstünde (ya da sağında ve solunda) bulunan beşer ya da üçer derece aracılığı ile belirlenmektedir (Vidali ve Holloway, 1975; Aytekin ve Durucasu, 2020). LBWA ve CoCoSo yöntemlerine ilişkin açıklayıcı bilgiler ise izleyen alt başlıklarda verilecektir.

\subsection{LBWA}

Karar probleminin çözümünde dikkate alınan kriterlerin çözüm üzerindeki etkilerinin belirlenmesi amacıyla ağırlıklandırma tekniklerinden yararlanılmaktadır. Ağırlıklandırma teknikleri ise nesnel, öznel ve karma olmak üzere üç sınıf altında değerlendirilmektedir. Nesnel ağırlıklandırma tekniklerinde karar matrisi veya veri yapısından yararlanılarak değişkenlik, benzerlik vb. gözetilerek kriterler ağırlıklandırımaktadır. Öznel ağılıklandırma tekniklerinde, karar vericinin tercihleri veya problemin bulunduğu alandaki uzman(lar)ın görüşleri doğrultusunda kriterlerin ağırlıklandırılması gerçekleştirilmektedir. Karma ağırıklandırma tekniklerinde ise söz konusu iki sınıftaki yaklaşımlar bütünleştirilerek ağılık değerleri belirlenmektedir. Bu çalışmada, öznel ağırlıklandırma tekniklerinden LBWA (Level Based Weight Assessment- Düzey Temelli Ağırlıklandırma Değerlendirmesi) kullanılacaktır. Zizovic ve Pamucar (2019) tarafından geliştirilmiş olan LBWA, kriterleri sıralı sınıflara bölerek değerlendirmeye olanak sağlaması nedeniyle tercih edilmiştir. Böylece, çalışmanın konusunu oluşturan problemde, birbirine yakın önemdeki kriterlerin etkin biçimde ağırlıklandırılması amaçlanmaktadır. LBWA'nın işlem adımları izleyen kısımda özetlenmiştir (Zizovic ve Pamucar, 2019): 
Adım 1. En önemli kriterin belirlenmesi: Çok kriterli karar problemlerinin çözümünde kullanılacak $n$ adet kriter; $j=1, \ldots, n$ olmak üzere belirlenir. Kriterler içinde, en önemli veya çözüm üzerinde en çok etkisi olacak kriter tespit edilir. Kriter kümesi $C=\left\{C_{1}, \ldots, C_{n}\right\}$ ve en önemli kriter $\mathrm{C}_{1}$ ile nitelendirilir.

Adım 2. Kriterlerin önem seviyelerine göre gruplandırılması: Kriterler önem seviyelerine göre $s=1, \ldots, z$ olmak üzere $G_{s}$ sınıfa/gruba ayrılır. Bu bağlamda, $G_{s}$ sınıfındaki $j$ kriteri $G_{s, j}$ ile ifade edilecektir. Öte yandan, problemde yer alan kriterlerin önem sıralaması $C_{k}$ ve en önemli $\operatorname{kriter} C_{1}$ ile gösterilmek üzere izleyen süreç takip edilir:

Seviye $1\left(G_{1}\right)$ : Bu seviyede yer alan kriterlerde, en önemli kriter $C_{1}$ 'e eşit veya $C_{1}{ }^{\prime}$ in en az yarısı derecesinde öneme sahiptir. Bu durum, $G_{1}$ 'de bulunan kriterler $G_{1, j}$ ile gösterilmek üzere eşitlik (1)'deki önem ilişkisi ile ifade edilebilir.

$$
\left[\frac{1}{2} C_{1}<G_{1, j}<C_{1}\right]
$$

Seviye $2\left(G_{2}\right)$ : Bu seviyedeki kriterler ile en önemli kriter arasındaki önem ilişkisi eşitlik (2)'de belirtilmiştir. Eşitlik (2)'de $G_{2, j}$ ikinci önem seviyesindeki kriterleri göstermektedir. $C_{1}$, ikinci seviyedeki kriterlerden en az iki, en fazla üç kata kadar daha önemli olabilmektedir.

$$
\left[\frac{1}{3} C_{1}<G_{2, j}<\frac{1}{2} C_{1}\right]
$$

Seviye $3\left(G_{3}\right)$ : Üçüncü seviyedeki kriterler ile en önemli kriter arasındaki önem ilişkisi eşitlik (3)'te belirtilmiştir. Eşitlik (3)'te $G_{3, j}$ üçüncü önem seviyesindeki kriterleri göstermektedir. $C_{1}$, üçüncü seviyedeki kriterlerden en az üç, en fazla dört kata kadar daha önemli olabilmektedir.

$$
\left[\frac{1}{4} C_{1}<G_{3, j}<\frac{1}{3} C_{1}\right]
$$

Seviye $z\left(G_{z}\right)$ : Karar verici, $s=1, . . z$ önem seviyelerini göstermek üzere $z$ adet seviye belirleyebilir. Buna göre $z$ seviyesindeki $G_{z, j}$ kriteri ile $C_{1}$ arasındaki önem ilişkisi eşitlik (4)'te verilmiştir. $C_{1}, z$ seviyedeki kriterlerden en az $z$, en fazla $z+1$ kata kadar daha önemli olabilmektedir.

$$
\left[\frac{1}{z+1} C_{1}<G_{z, j}<\frac{1}{z} C_{1}\right]
$$

Adım 3. Kriterlerin önem değerlendirmesi: Her bir seviyedeki kriterlere önemlerine göre değer ataması gerçekleştirilir. Bu amaçla kriterlerin karşılaştırılmasında kullanılacak kesikli (tam sayıları içeren) ölçeğin alt sınırı 0 iken üst sınırı ise sınıfların eleman sayıları dikkate alınarak eşitlik (5) yardımıyla belirlenir.

$$
r=\operatorname{maks}\left\{\left|n_{G_{1}}\right|,\left|n_{G_{2}}\right|, \ldots,\left|n_{G_{Z}}\right|\right\}
$$

Eşitlik (5)'te $n_{G_{S}}, G_{S}$ sınıfının eleman sayısını göstermektedir. Bu bağlamda, kriterlerin önem değerlendirilmesinde kullanılacak ölçek 0-r aralığında değerler alacaktır. Ayrıca, $G_{S}$ sınıfındaki $j$ kriteri $G_{s, j}$ olmak üzere, bu kriterin önem ölçeği değeri $I_{G_{s, j}}$ ile nitelendirilir. Aynı sınıfta yer alan $p$ ve $q$ kriterlerinin önem ölçeği değerleri $I_{G_{s, p}}$ ve $I_{G_{s, q}}$ gösterilmek üzere; $I_{G_{s, p}}=I_{G_{s, q}}$ eşit önemi, $I_{G_{s, p}}<I_{G_{s, q}}$ p kriterinin q kriterinden daha önemli olduğunu ve $I_{G_{s, p}}>$ $I_{G_{s, q}}$ ise q kriterinin $\mathrm{p}$ kriterinden daha önemli olduğunu belirtir.

Adım 4. Esneklik katsayısının belirlenmesi: Üçüncü adımda belirlenen $r$ değerinden büyük olmak şartı ile esneklik katsayısı $\left(r_{0}\right)$ belirlenir $\left(r_{0} \in N\right)$. 
Adım 5. Kriterlerin etki fonksiyonlarının hesaplanması: Her bir kriterin etki fonksiyonu $f\left(C_{j}\right)$ eşitlik (6) ile hesaplanır.

$$
f\left(C_{j}\right)=\frac{r_{0}}{\left(G_{s} \cdot r_{0}\right)+I_{G_{s, j}}}
$$

Eşitlik (6)'dan en önemli kriterin etki fonksiyonu değeri olan $f\left(C_{1}\right)^{\prime}$ in bire eşit olacağı anlaşılmaktadır.

Adım 6. Kriterlerin ağırlık değerlerinin elde edilmesi: Toplama dayalı doğrusal normalizasyon ile kriter ağırlık değerleri eşitlik (7)'de belirtilen biçimde hesaplanır:

$$
w_{j}=\frac{f\left(c_{j}\right)}{\sum_{j=1}^{n} f\left(c_{j}\right)}
$$

Eştilik (7) ile toplamları bire eşit olan ve 0-1 aralığında değerler alan kriter ağırlıkları elde edilir.

\subsection{CoCoSo}

Yazdani vd. (2019), karar alma süreçlerinde gri ilişkisel katsayısına dayanan ve sonuçların esnekliğini artırmayı hedefleyen bir mesafe ölçüsü çerçevesinde CoCoSo (COmbined COmpromise SOlution-Birleştirilmiş Uzlaşık Çözüm) yöntemini önermiştir. CoCoSo'da alternatiflerin öncelikleri üç farklı eşitlik ile değerlendirilmekte ve son adımda söz konusu öncelikler bütünleştirilerek genel sıralamalara ulaşılmaktadır.

CoCoSo yöntemi, SAW (Simple Additive Weighting; Basit Toplamsal Ağırlıklandırma) ve EWP (Exponentially Weighted Product; Üssel Ağırlıklandırılmış Çarpım) yöntemlerinin bütünleştirilmesine dayanmaktadır. CoCoSo yönteminin uygulanmasında izleyen işlem adımları takip edilir (Yazdani vd., 2019):

Adım 1. Karar matrisinin oluşturulması: Çok kriterli karar problemlerinin çözümünde sıklıkla karar matrisinden yararlanılır. Karar probleminin tanımlanması ve kriterler ile alternatiflerin belirlenmesinden sonra karar matrisi oluşturulur. Karar matrisi, sütunlarında kriterler, satırlarında alternatifler ve bunlara karşılık gelen gözelerde ise alternatiflerin ilgili kriterdeki performans, kalite ya da özellik değerini içeren, eşitlik (8)'de bir örneği verilen matristir.

$$
X=\left[\begin{array}{ccc}
x_{11} & \cdots & x_{1 n} \\
\vdots & \ddots & \vdots \\
x_{m 1} & \cdots & x_{m n}
\end{array}\right]
$$

Eşitlik (8)'de yer alan karar matrisi $X, j=1, \ldots, n$ kriterleri, $i=1, \ldots, m$ alternatifleri, $x_{i j} i$. alternatifin $j$. kriterdeki değerini gösteren elemanlar olmak üzere $m x n$ boyutlu matristir.

Adım 2. Karar matrisinin normalizasyonu: Normalizasyon işlemi için eşitlik (9)'dan yararlanilır.

$$
z_{i j}= \begin{cases}\frac{x_{i j}-\min _{i j}}{\operatorname{maks}_{i j}-\min _{i j} x_{i j}}, & j \in J^{+} \\ \frac{\operatorname{maks}_{i j}-x_{i j}}{\operatorname{maks}_{i} x_{i j}-\min _{i} x_{i j}} & , j \in J^{-}\end{cases}
$$

Eşitlik (9)' da $J^{+}$fayda yönlü kriterleri, $J^{-}$ise maliyet yönlü kriterleri göstermektedir. Çok kriterli karar problemlerinde $j$ kriterindeki değerler arttıkça alternatifin tercih edilirliği 
artıyorsa fayda optimizasyon yönü, $j$ kriterindeki değerler azaldıkça alternatiflerin tercih edilirliği artıyorsa maliyet optimizasyon yönü söz konusudur.

Adım 3. Gri ilişkisel ve çarpımsal karşılaştırma değerlerinin oluşturulması: Gri ilişkisel yaklaşım temelinde eşitlik (10) ile $S_{i}$ değerleri hesaplanır.

$$
S_{i}=\sum_{j=1}^{n} w_{j} z_{i j}
$$

WASPAS (Weighted Aggregated Sum Product Assessment- Ağılıklı Birleşik Toplu Çarpım Değerlendirmesi) yönteminde de kullanılan WPM (Weighted Product Model- Ağırlıklı Çarpım Modeli) temelinde $P_{i}$ değerleri, eşitlik (11) yardımıyla oluşturulur.

$$
P_{i}=\sum_{j=1}^{n}\left(z_{i j}\right)^{w_{j}}
$$

Adım 4. Alternatiflerin göreli değerlendirmelerinin yapılması: $S_{i}$ ve $P_{i}$ değerlerinin farklı etki düzeylerini içeren eşitlikler (12-14) kullanılarak alternatiflere ilişkin göreli değerlendirme skorları oluşturulur.

$$
\begin{aligned}
k_{i a} & =\frac{P_{i}+S_{i}}{\sum_{i=1}^{m}\left(P_{i}+S_{i}\right)} \\
k_{i b} & =\frac{S_{i}}{\min _{i} S_{i}}+\frac{P_{i}}{\min _{i} P_{i}} \\
k_{i c} & =\frac{\lambda s_{i}+(1-\lambda) P_{i}}{\lambda\left(\operatorname{maks}_{i}\right)+(1-\lambda)\left(\operatorname{maks}_{i} P_{i}\right)}
\end{aligned}
$$

Eşitlik (12)'de $P_{i}$ ve $S_{i}$ değerlerinin ortalamasının alındığı ve bu değerlerin $k_{i a}$ üzerinde eşit etkiye sahip olduğu görülmektedir. Eşitlik (13)'te $P_{i}$ ve $S_{i}$ değerlerinin bu değerlerdeki en küçük skora oranlanmasıyla $k_{i b}$ değeri elde edilmektedir. Eşitlik (14)'te ise WASPAS'taki bütünleşik genel değerlerin elde edilme sürecine benzer bir yaklaşım izlenerek dengeli bir değerlendirme elde edilmesi amaçlanmaktadır. CoCoSo yöntemini geliştiren Yazdani vd. (2019), $\lambda$ değerinin genellikle 0,5 seçildiğini belirtmiştir. Bununla birlikte, karar verici tarafından $\lambda$ için 0-1 aralığında farklı değerler seçilerek $P_{i}$ ve $S_{i}$ değerlerinin etki düzeyleri değiştirilebilir.

Adım 5. Alternatiflerin bütünleşik skorlarının oluşturulması: Alternatiflerin, eşitlikler (1214) kapsamında elde edilen göreli değerlendirmeleri, eşitlik (15) ile bütünleştirilir.

$k_{i}=\left(k_{i a} \cdot k_{i b} \cdot k_{i c}\right)^{\frac{1}{3}}+\frac{1}{3}\left(k_{i a}+k_{i b}+k_{i c}\right)$

Alternatifler, eşitlik (15) ile oluşturulan $k_{i}$ değerlerine göre büyükten küçüğe doğru sıralanır ve problemin çözümü tamamlanır.

\section{Uygulama ve Bulgular}

Büyükşehir belediyelerinin web sitelerinin çözümlenmesinde temel olarak açıklık, şeffaflık ve hesap verebilirlik düzeyinin elverişliliği ölçülmek istenmiştir. Bununla birlikte, büyükşehir belediyeleri web sitelerinde söz konusu yönetişim ilkelerine ilişkin bilgilerin ne ölçüde erişilebilir (halka açık) olduğunun tespit edilmesi ve tüm bunların zamanında ve eksiksiz bir biçimde vatandaşlarla paylaşılıp paylaşılmadığının ortaya çıkarılması da hedeflenmektedir. Bu bağlamda, web sitelerinin sağladığı bilgileri değerlendirmek üzere kamu bilgilerine erişim, şeffaflık ve hesap verebilirlik uygulamalarına ilişkin kriterler kullanılmıştır.

Her bir kriter belirlenirken büyükşehir belediye web siteleri göz önünde bulundurulmuş ve konu ile ilgili yayınlanmış çeşitli (Karakaya-Polat, 2006; Gandía ve Archidona, 2008; Aktel, 2009; Karkin ve Janssen, 2014; da Cruz vd., 2016; Rebolledo vd., 2017; Argüden vd., 2018; 
Kosova Democratic Institute ve NGO AKTIV, 2020) çalışmalardan yararlanılmıştır. Bu kapsamda, büyükşehir belediyelerinin web sitelerinde sağladıkları veya kullanıma sundukları yönetişim hizmetleri ve bilgi düzeyleri Tablo 1 'de yer verilen 13 kritere göre tespit edilmektedir.

Değerlendirmelerde yer alan 13 kriterle ilgili bilgiler (K1-K13) kamu bilgilerine erişim, şeffaflık ve hesap verebilirlik uygulamalarına ilişkindir. Bu bağlamda, Tablo 1'de hem kriterlerin ağırlık değerleri hem de 30 büyükşehir belediyesinin ilgili kriterlerdeki yeterlilik yüzdelerine ilişkin bilgiler yer almaktadır.

Tablo 1: Belediye Web İçeriklerinin Değerlendirilmesinde Kullanılan Kriterler ve Özet Bilgiler

\begin{tabular}{|c|c|c|c|c|c|c|}
\hline Kriterler & $\begin{array}{l}\text { Kriter } \\
\text { Kodu }\end{array}$ & $\begin{array}{l}\text { Ağırlık } \\
\left(w_{j}\right)\end{array}$ & Ort. & Med. & $\begin{array}{l}\text { Yeterlilik } \\
\text { Yüzdesi }\end{array}$ & $\begin{array}{l}\text { Yetersizlik } \\
\text { Yüzdesi }\end{array}$ \\
\hline $\begin{array}{l}\text { Büyükşehir belediye başkanı hakkında genel bilgiler (özgeçmiş ve } \\
\text { iletişim bilgileri) ve büyükşehir belediye organlarının (başkan, } \\
\text { meclis, encümen ve komisyon üyeleri) görev alanlarını gösteren } \\
\text { organizasyon (teşkilat) şeması bulunmakta mı? }\end{array}$ & K1 & 0,0373 & $-0,13$ & $-1,00$ & 30,00 & 70,00 \\
\hline $\begin{array}{l}\text { Büyükşehir belediye web sitesinde meclis gündemleri, meclis } \\
\text { kararları/tutanakları (toplantı tarihleri ve yerleri ile ilgili birlikte) } \\
\text { ve meclis ile encümen üyeleri hakkında bilgiler bulunmakta mı? }\end{array}$ & K2 & 0,1073 & $-0,17$ & $-1,00$ & 30,00 & 70,00 \\
\hline $\begin{array}{l}\text { Ihtisas/meclis komisyonları ve etik komisyonu üyelerine ilişkin } \\
\text { bilgiler büyükşehir belediyesi web sitesinde yer alıyor mu? }\end{array}$ & K3 & 0,0858 & 0,50 & 1,00 & 53,33 & 46,67 \\
\hline $\begin{array}{l}\text { Büyükşehir belediyesinin mali yıla ilişkin bütçesi ile mali durum ve } \\
\text { beklentiler raporu yayınlanıyor mu? }\end{array}$ & K4 & 0,1226 & 0,83 & 1,00 & 70,00 & 30,00 \\
\hline $\begin{array}{l}\text { Büyükşehir belediyesinin stratejik planı web sitesinde } \\
\text { yayınlanıyor mu? }\end{array}$ & K5 & 0,1226 & 1,97 & 2,00 & 93,33 & 6,67 \\
\hline $\begin{array}{l}\text { Büyükşehir belediyesinin yıllık faaliyet raporları web sitesinde var } \\
\text { mı? }\end{array}$ & K6 & 0,1226 & 2,10 & 3,00 & 86,67 & 13,33 \\
\hline $\begin{array}{l}\text { Büyükşehir belediyesinin performans programları web sitesinde } \\
\text { var mı? }\end{array}$ & K7 & 0,1226 & 2,37 & 3,00 & 90,00 & 10,00 \\
\hline $\begin{array}{l}\text { Web sitesinde, Ulaşım Koordinasyon Merkezi (UKOME) kararları } \\
\text { yayınlanmakta mı? }\end{array}$ & K8 & 0,0390 & $-0,57$ & 1,00 & 56,67 & 43,33 \\
\hline $\begin{array}{l}\text { Web sitesinde, kamu ihale ve satın alma anlaşmaları duyurulmuş } \\
\text { mu? }\end{array}$ & K9 & 0,0505 & 0,83 & 1,00 & 80,00 & 20,00 \\
\hline Sayıştay denetimi (dış denetim) raporları açıklanmış mı? & K10 & 0,0572 & $-2,23$ & $-3,00$ & 13,33 & 86,67 \\
\hline $\begin{array}{l}\text { Kamuoyunu bilgilendirme raporu (iç denetim raporu) açıklanmış } \\
\text { mı? }\end{array}$ & K11 & 0,0505 & $-2,03$ & $-2,50$ & 6,67 & 93,33 \\
\hline $\begin{array}{l}\text { Büyükşehir belediyesinde yürütülen ve tamamlanan projeler } \\
\text { hakkında bilgiler var mı? }\end{array}$ & K12 & 0,0477 & $-0,50$ & $-1,00$ & 46,67 & 53,33 \\
\hline $\begin{array}{l}\text { Büyükşehir belediyesinin yerele ilişkin yayınlar; e-haber bülteni, } \\
\text { e-gazete, e-dergi, broşür vb. var mı? }\end{array}$ & K13 & 0,0343 & $-0,97$ & $-1,00$ & 33,33 & 66,67 \\
\hline
\end{tabular}

Tablo 1'de yer alan kriterlere göre web sitelerinin Stapel ölçeği ile değerlendirilmesi "yeterli" ifadesi üzerinden gerçekleştirilmiştir. Ölçeklendirme kapsamında öncelikle, yönetişim ilkeleri ile uyumlu olarak büyükşehir belediyeleri-vatandaş ilişkisi çerçevesinde web sitelerinde yayınlanan bilgiler değerlendirilmiştir. Ayrıca, bu araştırma kapsamında büyükşehir belediyelerinin güncel web siteleri, yönetişim temelli ve vatandaş odaklı bilgi ve hizmet sunma yönünden 22 Aralık 2020 ve 15 Ocak 2021 tarihleri arasında, içerik analizi yöntemiyle incelenmiştir. Bu kapsamda, örneklemde yer alan büyükşehir belediyeleri web siteleri ile ilgili tespitler, söz konusu web siteleri ile ilgili bilgilerin güncellenme durumunun olması sebebiyle yalnızca ilgili dönem ile ilişkilendirilebilir. Bununla birlikte, bu araştırma ile web sitelerinin ilgili ana ve alt kriterleri ne ölçüde karşıladığı tespit edilmiştir. Buna göre, Stapel ölçeğinde yer alan pozitif değerler yeterli, negatif değerler ise yetersiz başlığı altında yüzdesel olarak özet biçimde sunulmuştur. Ayrıca, değerlendirmelerin ortalama ve medyan değerlerine de yer 
verilmiştir. Belediyelerin en yeterli olduğu kriterin $\mathrm{K} 5$, en az yeterli olduğu kriterin ise $\mathrm{K} 11$ olduğu Tablo 1'den anlaşılmaktadır.

Kriterlerin ağırlıklandııılması sürecinde ise LBWA tekniğinden yararlanılmıştır. Türkiye'de kamu yönetiminde yönetişim ilkeleri dikkate alındığında açıklık, şeffaflık ve hesap verebilirliğin sağlanmasında 5018 sayılı Kanun ile yerel yönetimler yönünden 5393 sayılı Belediye Kanunu önemli referans kaynaklarıdır. Bu bağlamda, kriterlerin ağırlıklandırılmasında genel itibariyle yürürlükte olan mevzuat temelinde değerlendirmeler yapılmıştır. Tablo 1'de ağırlıklandırma yönünden en önemli kriterlerin K4, K5, K6 ve K7 olduğu görülmektedir. Tablo 1'de yer alan bilgiler ışığında, en önemli dört kriterde belediye web siteleri içeriklerinin yeterlilik düzeyinin ortalama ve üstü olduğu tespit edilmektedir. Bu bağlamda, büyükşehir belediye web siteleri genel itibariyle mevzuatın gerektirdiği kamu bilgilerine erişim ve şeffafık ile ilgili düzenlemeleri karşılamaktadır. Öte yandan, kamu yönetiminde şeffaflıkla doğrudan ilgili K2 ve özellikle denetim ve hesap verebilirlikle doğrudan ilişkili olan K10 ve K11 açısından ise büyükşehir belediye web siteleri ortalamanın altında görünmektedir. Ayrıca, yine tabloya göre K1, K12 ve K13'te yeterlilik düzeyi açısından eksiktirler. Bununla birlikte, geri kalan kriterlerin ortalamanın üstünde olduğu tespit edilmiştir.

Ölçeklendirme işlemlerinin ardından karar matrisi CoCoSo yöntemi uygulamak üzere hazırlanmıştır. Çalışma kapsamında belirlenen 13 temel kriter bağlamında gerçekleştirilen çözümlemeler sonucunda elde edilen özet bilgiler Tablo 2'de sunulmaktadır.

Tablo 2: Belediye Web İçeriklerine İlişkin Değerlendirmelerin Özet Bilgileri

\begin{tabular}{|c|c|c|c|c|c|c|c|c|c|c|}
\hline $\begin{array}{l}\text { Büyükşehir } \\
\text { Belediyeleri }\end{array}$ & Ort. & Med. & $\begin{array}{c}3 \\
\text { Yüzdesi }\end{array}$ & $\begin{array}{c}2 \\
\text { Yüzdesi }\end{array}$ & $\begin{array}{c}1 \\
\text { Yüzdesi }\end{array}$ & $\begin{array}{c}-1 \\
\text { Yüzdesi }\end{array}$ & $\begin{array}{c}-2 \\
\text { Yüzdesi }\end{array}$ & $\begin{array}{c}-3 \\
\text { Yüzdesi }\end{array}$ & $\begin{array}{c}\text { Yeterlilik } \\
\text { Yüzdesi }\end{array}$ & $\begin{array}{c}\text { Yetersizlik } \\
\text { Yüzdesi }\end{array}$ \\
\hline İstanbul & 1,08 & 1 & 15,38 & 30,77 & 38,46 & 0,00 & 7,69 & 7,69 & 84,62 & 15,38 \\
\hline Ankara & 1,54 & 3 & 61,54 & 0,00 & 15,38 & 7,69 & 7,69 & 7,69 & 76,92 & 23,08 \\
\hline İzmir & 2,08 & 3 & 53,85 & 23,08 & 15,38 & 0,00 & 7,69 & 0,00 & 92,31 & 7,69 \\
\hline Adana & 0,38 & 1 & 38,46 & 7,69 & 7,69 & 15,38 & 7,69 & 23,08 & 53,85 & 46,15 \\
\hline Antalya & 0,23 & 1 & 38,46 & 0,00 & 15,38 & 15,38 & 0,00 & 30,77 & 53,85 & 46,15 \\
\hline Aydın & $-0,62$ & -2 & 23,08 & 7,69 & 7,69 & 7,69 & 15,38 & 38,46 & 38,46 & 61,54 \\
\hline Balıkesir & 0,38 & 1 & 23,08 & 15,38 & 23,08 & 15,38 & 0,00 & 23,08 & 61,54 & 38,46 \\
\hline Bursa & 0,92 & 1 & 30,77 & 7,69 & 38,46 & 7,69 & 0,00 & 15,38 & 76,92 & 23,08 \\
\hline Denizli & 0,46 & 1 & 15,38 & 23,08 & 15,38 & 38,46 & 0,00 & 7,69 & 53,85 & 46,15 \\
\hline Diyarbakır & $-0,92$ & -1 & 7,69 & 7,69 & 7,69 & 38,46 & 15,38 & 23,08 & 23,08 & 76,92 \\
\hline Erzurum & 0,46 & 1 & 30,77 & 7,69 & 15,38 & 30,77 & 0,00 & 15,38 & 53,85 & 46,15 \\
\hline Eskişehir & 0,08 & -1 & 38,46 & 0,00 & 7,69 & 23,08 & 0,00 & 30,77 & 46,15 & 53,85 \\
\hline Gaziantep & $-0,69$ & -1 & 7,69 & 15,38 & 15,38 & 15,38 & 15,38 & 30,77 & 38,46 & 61,54 \\
\hline Hatay & $-0,62$ & -1 & 7,69 & 15,38 & 23,08 & 7,69 & 7,69 & 38,46 & 46,15 & 53,85 \\
\hline K. Maraş & 0,08 & -1 & 23,08 & 7,69 & 15,38 & 30,77 & 7,69 & 15,38 & 46,15 & 53,85 \\
\hline Kayseri & 0,46 & 1 & 30,77 & 7,69 & 15,38 & 30,77 & 0,00 & 15,38 & 53,85 & 46,15 \\
\hline Kocaeli & 0,15 & -1 & 30,77 & 7,69 & 7,69 & 30,77 & 0,00 & 23,08 & 46,15 & 53,85 \\
\hline Konya & $-0,85$ & -1 & 0,00 & 15,38 & 7,69 & 53,85 & 0,00 & 23,08 & 23,08 & 76,92 \\
\hline Malatya & $-0,31$ & -1 & 23,08 & 7,69 & 15,38 & 15,38 & 0,00 & 38,46 & 46,15 & 53,85 \\
\hline Manisa & 0,62 & 1 & 23,08 & 15,38 & 23,08 & 23,08 & 7,69 & 7,69 & 61,54 & 38,46 \\
\hline Mardin & $-2,23$ & -3 & 0,00 & 0,00 & 15,38 & 0,00 & 15,38 & 69,23 & 15,38 & 84,62 \\
\hline Mersin & 1,00 & 1 & 46,15 & 0,00 & 23,08 & 15,38 & 0,00 & 15,38 & 69,23 & 30,77 \\
\hline Muğla & 0,62 & 1 & 23,08 & 15,38 & 23,08 & 23,08 & 7,69 & 7,69 & 61,54 & 38,46 \\
\hline Ordu & 1,08 & 2 & 46,15 & 7,69 & 15,38 & 15,38 & 0,00 & 15,38 & 69,23 & 30,77 \\
\hline Sakarya & 0,85 & 1 & 38,46 & 0,00 & 30,77 & 15,38 & 0,00 & 15,38 & 69,23 & 30,77 \\
\hline Samsun & $-0,46$ & -1 & 23,08 & 0,00 & 7,69 & 38,46 & 7,69 & 23,08 & 30,77 & 69,23 \\
\hline Ş. Urfa & $-0,54$ & -1 & 0,00 & 15,38 & 30,77 & 15,38 & 15,38 & 23,08 & 46,15 & 53,85 \\
\hline Tekirdağ & 0,38 & 1 & 23,08 & 7,69 & 30,77 & 15,38 & 7,69 & 15,38 & 61,54 & 38,46 \\
\hline Trabzon & 0,46 & 1 & 23,08 & 15,38 & 23,08 & 15,38 & 7,69 & 15,38 & 61,54 & 38,46 \\
\hline Van & $-1,46$ & -2 & 0,00 & 0,00 & 30,77 & 7,69 & 15,38 & 46,15 & 30,77 & 69,23 \\
\hline
\end{tabular}


Tablo 2'de 13 kriter genelinde, büyükşehir belediyelerin $+3,+2,+1,-1,-2$ ve -3 değerlerine ilişkin yüzdeleri, ortalamaları ve medyan değerleri bulunmaktadır. Ayrıca, pozitif değerler yeterli, negatif değerler ise yetersiz başlığı altında yüzdesel olarak özet biçimde verilmiştir. Tablo 2'de yer alan değerlendirmelere ilişkin ayrıntılar izleyen alt başlıkta sunulmaktadır.

\subsection{Büyükşehir Belediyeleri Web Sitelerine İlişkin Kamusal Bilgilere Erişim, Şeffaflık ve Hesap Verebilirlikle İlgili Bulgular}

K1: Büyükşehir belediye başkanı hakkında genel bilgiler (özgeçmiş ve iletişim bilgileri) ve büyükşehir belediye organlarının (başkan, meclis, encümen ve komisyon üyeleri) görev alanlarını gösteren organizasyon (teşkilat) şeması bulunmakta mı?

Kurumsal web sitelerinde büyükşehir belediye başkanı ile ilgili genel bilgiler (özgeçmiş ve iletişim bilgileri) sunan büyükşehir belediyeleri İstanbul, İzmir, Antalya, Balıkesir, Bursa, Eskişehir, Ordu, Sakarya ve Tekirdağ'dır. Diğer 21 büyükşehir belediye web sitelerinde, büyükşehir belediye başkanının yalnızca özgeçmiş bilgileri yer almaktadır. Ayrıca, İzmir büyükşehir belediyesi web sitesinde başkanın mal beyanı ve sosyal medya hesaplarına ilişkin bilgiler de yer almaktadır. Başkanın sosyal medya hesaplarının paylaşıldığı diğer büyükşehir belediyeler şunlardır: Balıkesir, Denizli, Eskişehir, Kahramanmaraş, Kocaeli, Malatya, Muğla, Ordu, Samsun, Trabzon ve Van. Mardin büyükşehir belediyesi haricinde kalan diğer tüm büyükşehir belediyelerinin kurumsal web sitelerinde belediyenin organizasyon (teşkilat) şeması bulunmaktadır.

K2: Büyükşehir belediye web sitesinde meclis gündemi, meclis kararları/tutanakları (toplantı tarihleri ve yerleri ile ilgili birlikte) ve meclis ile encümen üyeleri hakkında bilgiler bulunmakta midır?

Büyükşehir belediye meclislerinin gündemleri, kararları ve üyeleri ile ilgili bilgilerin web sitelerinde yayınlanması açıklık, şeffaflık ve hesap verebilirlik bakımından önemlidir. Yerel yönetim organları ve aldıkları kararlar hakkında vatandaşların bilgi sahibi olmaları, yerel demokrasi ve hesap verebilirlik ilkesinin gelişmesine katkı sağlamaktadır. Bu bilgilere tam olarak yer veren büyükşehir belediyeleri sırasıyla; İstanbul, Ankara, İzmir, Adana, Antalya, Mersin, Sakarya ve Trabzon'dur. Ayrıca, İzmir büyükşehir belediyesi encümen gündemini ve kararlarını da açıklanmaktadır. Bursa ve Samsun büyükşehir belediyeleri web sitelerinde yalnızca meclis gündemleri, kararları ve toplantı tutanakları açıklanmaktadır. Söz konusu büyükşehir belediyelerinin web sitelerinde, encümen üyeleri ile ilgili herhangi bir bilgi bulunmamaktadır. Diyarbakır ve Van büyükşehir belediye web sitelerinde yalnızca meclis kararları yer almaktadır.

Aydın, Erzurum, Eskişehir, Hatay, Kocaeli ve Malatya büyükşehir belediyeleri web sitelerinde ise yalnızca meclis üyeleri, gündemleri ve toplantı karar özetleri bulunmaktadır. Balıkesir, Denizli, Kayseri, Kahramanmaraş, Konya, Manisa, Muğla ve Ordu büyükşehir belediyeleri web sitelerinde ise meclis ve encümen üyeleri, meclis gündemleri ve karar özetleri sunulmaktadır. Şanlıurfa ve Tekirdağ büyükşehir belediyelerinin web sitelerinde meclis ve encümen üyeleri ile meclis karar özetlerine erişmek olanaklıdır. Son olarak, Gaziantep büyükşehir belediyesinin resmî web sitesinde yalnızca meclis ve encümen üyeleri ile ilgili bilgiler bulunmaktadır. 
K3: ihtisas/meclis komisyonları ve etik komisyonu üyelerine ilişkin bilgiler büyükşehir belediyesi web sitesinde yer alıyor mu?

intisas komisyonlarına ilişkin bilgilerin web sitelerinde yayınlandığı büyükşehir belediyeleri arasında İstanbul, Ankara, İzmir, Adana, Antalya, Balıkesir, Bursa, Erzurum, Eskişehir, Kahramanmaraş, Konya, Malatya, Manisa, Muğla, Ordu, Samsun, Şanlıurfa, Tekirdağ ve Trabzon yer almaktadır. Buna karşılık, Denizli, Gaziantep, Kayseri ve Kocaeli büyükşehir belediyelerinin kurumsal web sitelerinde ihtisas/meclis komisyonları hakkında herhangi bir bilgi bulunmamaktadır.

Kamu Görevlileri Etik Davranış Illkeleri ile Başvuru Usul ve Esasları Hakkında Yönetmelik (Madde 29) büyükşehir belediyelerinde en az üç kişilik bir etik komisyonu kurulması zorunluluğunu getirmiştir. Etik komisyonların, kamu kurumlarında etik ile ilgili sorunlara yönelik hassasiyetin gelişmesine, etik uygulamaların değerlendirilmesine, bir diğer deyişle açıklık, şeffaflık ve hesap verebilirlik konularında kurumsallaşmaya katkı sağlaması beklenmektedir. Etik komisyon üyeleri hakkında web sitelerinde bilgi verilen büyükşehir belediyeleri sırasıyla; İstanbul, Ankara, İzmir, Adana, Bursa, Denizli, Erzurum, Eskişehir, Gaziantep, Kayseri, Kahramanmaraş, Kocaeli, Malatya, Manisa, Muğla, Ordu, Şanlıurfa, Tekirdağ ve Trabzon'dur. Ayrıca, Antalya, Balıkesir, Konya ve Samsun büyükşehir belediyeleri web sitelerinde etik komisyon üyeleri hakkında herhangi bir bilgi yer almamaktadır. Buna karşılık, Aydın, Diyarbakır, Hatay, Mardin, Sakarya ve Van büyükşehir belediyeleri web sitelerinde ne ihtisas/meclis komisyonlarına ne de etik komisyonlarına ilişkin herhangi bir bilgi bulunmamaktadır. Son olarak, Ankara, İzmir, Kahramanmaraş, Mersin, Muğla, Ordu, Samsun, Tekirdağ ve Trabzon büyükşehir belediyeleri web sitelerinde meclis/ihtisas komisyon raporları ya da kararları yayınlanmaktadır.

K4: Büyükşehir belediyesinin mali yıla ilişkin bütçesi ile mali durum ve beklentiler raporu yayınlanıyor mu?

5018 sayılı Kanunun mali saydamlık ilkesi gereğince kamu kurumlarının ve dolayısıyla yerel yönetimlerin, mali yılı bütçelerini hazırlamaları, bütçelerine ilişkin beklentiler ve gerçekleşme raporlarını kamuoyuna açık ve ulaşılabilir biçimde paylaşmaları gerekmektedir. Bu kapsamda hem güncel hem de geçmiş yıllara ait mali yılı bütçesi ile mali durum ve beklentiler raporu web sitesinde yayınlanan büyükşehir belediyeleri sırasıyla; İzmir, Adana, Antalya, Balıkesir, Bursa, Kocaeli, Mersin, Muğla ve Sakarya'dır. İstanbul büyükşehir belediyesi web sitesinde ise yalnızca güncel mali bütçe, mali durum ve beklentiler raporu yer almaktadır. Ayrıca, Ankara büyükşehir belediyesi web sitesinde ise hem güncel hem de geçmiş yıllara ait mali yılı bütçesi olmakla birlikte mali durum ve beklentiler raporlarının güncel olmadığı görülmüştür.

Web sitesinde Mali yıla ilişkin bütçesi bulunmayıp, yalnızca güncel ve geçmişe dönük olarak mali durum ve beklentiler raporu bulunan büyükşehir belediyeleri sırasıyla; Aydın, Erzurum, Eskişehir, Gaziantep, Hatay, Kayseri, Kahramanmaraş, Manisa, Ordu, Samsun, Tekirdağ ve Van'dır. Buna karşılık, yalnızca kurumsal durum ve mali beklentiler raporu bulunan büyükşehir belediyeleri ise Denizli ve Diyarbakır'dır. Ayrıca, Şanlıurfa büyükşehir belediyesi web sitesinde ise mali yıla ilişkin bütçe, mali durum ve beklentiler raporları güncel bir biçimde yer almamaktadır. Trabzon büyükşehir belediyesi web sitesinde ise yalnızca 2020 yılı mali gelir gider tablolarını içeren bütçe uygulama sonuçlarına yer verilmiştir. Bu bölümde değerlendirdiğimiz kritere ilişkin herhangi bir belgeye erişim sağlanamayan büyükşehir belediyeleri ise sırasıyla; Konya, Mardin ve Malatya'dır. 


\section{K5: Büyükşehir belediyesinin stratejik planı web sitesinde yayınlanıyor mu?}

Stratejik planlar, kamu idarelerinin (merkezi yönetim organları, büyükşehir belediyeleri ve belediyeler gibi) her türlü kaynaklarının ileriye dönük olarak nasıl tasarruf edileceği ile ilgili konularda oluşturulmaktadır. 5018 sayılı Kanun gereği, büyükşehir belediyelerinin orta ve uzun vadeli amaçlarını, temel ilkelerini, politikalarını ve hedeflerini stratejik planlar oluşturarak kamuoyuyla paylaşmaları ve bu planlara vatandaşların erişimini sağlamaları açıklık ve şeffaflık ilkesinin bir gereğidir. Bu bağlamda gerek güncel gerekse geçmiş yıllara ilişkin stratejik plan belgelerini web sitelerinde yayınlayan büyükşehir belediyeleri sırasıyla; Ankara, İzmir, Adana, Antalya, Aydın, Balıkesir, Bursa, Erzurum, Eskişehir, Gaziantep, Hatay, Kayseri, Kocaeli, Malatya, Manisa, Mersin, Muğla, Ordu, Sakarya, Samsun, Şanlıurfa, Tekirdağ ve Trabzon'dur. Ayrıca, Denizli, Diyarbakır, Kahramanmaraş ve Van büyükşehir belediyeleri, yalnızca güncel stratejik planlarını web sitelerinde paylaşmaktadır.

İstanbul ve Konya büyükşehir belediyeleri web sitelerinde yer alan stratejik planlara, kullanıcı kolaylığı ve görünürlük yönünden sorunlu bir biçimde erişim sağlanabilmektedir. İstanbul büyükşehir belediyesinin güncel stratejik planına, web sitesinde yer alan aramalar sekmesi yoluyla erişim sağlanmaktadır. Son olarak, web sitesinde stratejik planla ilgili herhangi bir belge yayınlamayan ve paylaşmayan bir tek Mardin büyükşehir belediyesidir.

\section{K6: Büyükşehir belediyesinin güncel faaliyet raporu web sitesinde var mı?}

5018 sayılı Kanun (Madde $41 / 2$ ve son) gereği yerel yönetimlerin faaliyet raporlarını oluşturmaları ve 5393 sayılı Belediye Kanunu (Madde 56/2) uyarınca belediyelerin faaliyet raporlarını açıklık ve şeffaflık anlayışı doğrultusunda kamuoyu ile paylaşılmalarını zorunlu tutmaktadır. Bu bağlamda, Diyarbakır büyükşehir belediyesinin web sitesinde yalnızca 2017 yılına ilişkin faaliyet raporu yer alırken, Van büyükşehir belediyesi web sitesinde ise 2017 ve 2018 yıllarına ilişkin faaliyet raporları yer almaktadır.

Konya büyükşehir belediye web sitesinde faaliyet raporları, kullanıcı kolaylığı ve görünürlük yönünden sorunlu bir erişim (doğrudan bir bağlantı kurulamadan veya sekme bulunmadan) sağlamaktadır. Son olarak, Mardin büyükşehir belediye web sitesinde ise faaliyet raporları ile ilgili herhangi bir belgeye erişim sağlanamamaktadır. Geri kalan 26 büyükşehir belediyesi hem güncel hem de geçmiş yıllara ilişkin faaliyet raporlarını web sitelerinde yayınlamaktadır.

\section{K7: Büyükşehir belediyesinin performans programları web sitesinde var mı?}

5018 sayılı Kanun (Madde 9/4 ve 41) gereğince, yerel yönetimlerde mali ve performans denetimi bağlamında yıllık performans programının oluşturulması ve oluşturulan bu performans programının kamuoyu ile paylaşıması gerekmektedir. İstanbul ve Konya büyükşehir belediyeleri web sitelerinde yer alan performans programlarına, kullanıcı kolaylığı ve görünürlük yönünde kolay erişim sağlanamamaktadır. Diyarbakır büyükşehir belediyesinin web sitesinde, yalnızca 2017, 2018 ve 2019 yıllarına ilişkin performans programları bulunmaktadır. Son olarak, Mardin büyükşehir belediyeleri kurumsal web sitesinde, performans programları ile ilgili herhangi bir belgeye ulaşılamamıştır. Geri kalan 26 büyükşehir belediyesinin güncel ve geçmiş yıllara ilişkin performans programları kurumsal web sitelerinde yer almaktadır. 


\section{K8: Web sitesinde Ulașım Koordinasyon Merkezi (UKOME) kararları yayınlanmakta mı?}

Kurumsal web sitesinde UKOME kararlarını yayınlayan büyükşehir belediyeleri sırasıyla; İstanbul, Ankara, İzmir, Bursa, Denizli, Erzurum, Hatay, Konya, Mardin, Malatya, Manisa, Mersin, Muğla, Sakarya, Tekirdağ, Trabzon ve Van'dır. Buna karşılık, Adana, Diyarbakır ve Samsun büyükşehir belediyeleri web sitelerinde güncel UKOME kararları bulunmayıp, ulaşım ve koordinasyon kararları ile ilgili yalnızca geçmiş dönemlere ilişkin bilgiler yer almaktadır. Geri kalan 10 büyükşehir belediyesinin kurumsal web sitesinde UKOME kararları ile ilgili herhangi bir bilgi bulunmamaktadır.

K9: Web sitesinde, kamu ihale ve satın alma anlaşmaları duyurulmuş mu?

4734 sayılı Kamu ihale Kanunu (Madde 2, 13, 22 ve 62) gereğince yerel yönetimlerin mal, hizmet alımları gibi satın alma işlemleri ve yapım işlerinin ihaleleri, söz konusu kanun hükümlerine göre yürütülmektedir. Yerel yönetimlerin güncel ihale ve satın alma bilgilerini kurumsal web siteleri aracılığıyla kamuoyu ile paylaşması fırsat eşitliği, açıklık ve şeffaflık ilkelerinin gerçekleşmesine katkı sağlamaktadır.

Aydın, Denizli, Diyarbakır, Eskişehir, Samsun ve Van büyükşehir belediye web sitelerinde ihale ve satın alma anlaşmalarına ilişkin herhangi bir bilgi yer almamaktadır. Denizli ve Diyarbakır büyükşehir belediyeleri web sitelerinde geçmiş yıllara ilişkin ihale bilgileri yer almakla birlikte güncel ihale bilgileri bulunmamaktadır. Geri kalan 24 büyükşehir belediyesinin kurumsal web sitelerinde ihale duyuruları hakkında bilgi verilmektedir. Ayrıca, Ankara büyükşehir belediye web sitesinde 2020 yılına ilişkin büyükşehir belediyesi ihale ve satın alma işlemleriyle ilgili rapor da yer almaktadır.

\section{K10: Sayıştay denetimi (dış denetim) raporları açıklanmış mı?}

Kamu kurumları ve yerel yönetimlerin iç ve dış denetimlerine olanak sağlayan 5018 sayılı Kanun (Madde 41) gereğince, İstanbul, Ankara, İzmir ve Denizli büyükşehir belediyeleri web sitelerinde, Sayıştay denetimi (dış denetim) ile ilgili raporlar yayınlanmaktadır. Bununla birlikte, Ankara büyükşehir belediyesinin Sayıştay denetim raporları hem güncel ve hem de geçmişe dönük olarak kurumsal web sitesinde yer almaktadır. Adana büyükşehir belediyesi web sitesinde ise yalnızca güncel olmayan Sayıştay raporları bulunmaktadır. Geri kalan 25 büyükşehir belediye web sitelerinin hiçbirinin web sitesinde Sayıştay raporu ile ilgili herhangi bir bilgi bulunamamıştır.

\section{K11: Kamuoyunu bilgilendirme raporu (İç denetim raporu) açıklanmış mı?}

iç denetim, yönetsel faaliyetlerin izlenerek, kurum hedeflerinin gerçekleştirilmesini engelleyebilecek riskler ile bu risklerin giderilmesine yönelik denetimlere yönelik öneriler geliştirilmesini amaçlamaktadır (5018 sayılı Kanun Madde 55 ve 56). Büyükşehir belediyeleri harcamalarının toplam kamu harcamaları içinde artan oranı, etkin ve verimli bir iç denetim sisteminin kurulmasını zorunlu kılmıştır (Ağmaz, 2017). Ankara ve Diyarbakır büyükşehir belediyelerinin kurumsal web sitelerinde iç denetim raporlarına yer verilmektedir. Eskişehir, Kayseri, Konya, Mersin, Ordu ve Samsun büyükşehir belediyeleri web sitelerinde ise hem güncel hem de geçmiş yıllara ilişkin kamu iç kontrol standartlarına uyum eylem planları yayınlanırken; İzmir, Aydın, Kahramanmaraş, Manisa, Muğla ve Tekirdağ büyükşehir belediye web sitelerinde güncel olmamakla birlikte kamu iç kontrol standartlarıyla uyumlu eylem planları paylaşılmaktadır. Sakarya büyükşehir belediyesi web sitesinde iç kontrol standartlarına uyum eylem planı, yalnızca güncel olarak paylaşılmaktadır. Geri kalan 15 
büyükşehir belediyesinin resmî web sitelerinde, iç denetim raporları ile ilgili herhangi bir bilgi bulunmamaktadır.

K12: Büyükşehir belediyesinde yürütülen ve tamamlanan projeler hakkında bilgiler var mı?

Tamamlanan, süren ve planlanan projelerle ilgili kurumsal web sitelerinde bilgi sunan büyükşehir belediyeleri sırasıyla; Aydın, Balıkesir, Bursa, Denizli, Diyarbakır, Erzurum, İzmir, Kayseri, Kocaeli, Manisa, Mersin, Ordu, Sakarya ve Şanlıurfa'dır. Kahramanmaraş büyükşehir belediyesi web sitesinde yalnızca süren projelerle ilgili bilgiler bulunmaktadır. Muğla ve Tekirdağ büyükşehir belediyelerinin web sitelerinde ise yalnızca geçmiş yıllara ilişkin projelerle ilgili bilgiler paylaşılmaktadır. Samsun ve Trabzon büyükşehir belediye web sitelerinde projelerle ile ilgili genel bilgiler olmakla birlikte projelerin tarihi ile ilgili bilgiler yer almamaktadır. Öte yandan, İstanbul, Ankara, Adana, Antalya, Eskişehir, Hatay, Konya, Malatya ve Van büyükşehir belediyeleri resmî web sitelerinde projelerle ilgili herhangi bir bilgi paylaşmamaktadır. Bununla birlikte, İstanbul, Gaziantep ve Mardin büyükşehir belediye web sitelerinde "projeler" sekmesi bulunmakla birlikte, "içerik hazırlanıyor ve geçici olarak hizmet dışı" uyarısı yer almaktadır.

K13: Büyükşehir belediyesinin yerele ilişkin yayınları; e-haber bülteni, e-gazete, e-dergi, broşür vb. var mı?

Balıkesir, Bursa, Denizli, İstanbul, İzmir, Kayseri, Kahramanmaraş, Konya, Ordu ve Trabzon büyükşehir belediyeleri web sitelerinde yerel gelişmeleri konu alan bülten ve dergi gibi yayınlar bulunmaktadır. Öte yandan, kurumsal web sitesinde herhangi bir yayın bilgisi paylaşmayan büyükşehir belediyeleri sırasıyla; Ankara, Adana, Aydın, Diyarbakır, Gaziantep, Hatay, Mardin, Malatya, Mersin, Samsun, Tekirdağ ve Van'dır. Bununla birlikte, Antalya, Erzurum, Eskişehir, Kocaeli, Manisa, Muğla, Sakarya ve Şanlıurfa büyükşehir belediyeleri web sitelerinde geçmiş yıllardaki yayınlara ilişkin içerikler bulunmaktadır.

Araştırmada dikkate alınan kriterler bağlamında büyükşehir belediyelerinin web sitelerine ilişkin olarak yeterlilik ve eksiklik değerlendirmeleri yapıldıktan sonra, bu alanda yapılmış çalışmalar dikkate alınarak özet bilgilerin verildiği Tablo 1 ve Tablo 2'deki değerlere ulaşılmıştır. Ardından, Tablo 1'de yer alan kriter ağırlıkları ve karar matrisi değerlerinden yararlanarak CoCoSo yöntemiyle Tablo 3'te belirtilen sonuçlar elde edilmiştir. 
Tablo 3: Belediye Web İçeriklerinin Açıklık, Şeffaflık ve Hesap verebilirlik Bağlamında Sıralanması

\begin{tabular}{|c|c|c|c|c|c|c|c|c|c|c|}
\hline $\begin{array}{l}\text { Büyükşehir } \\
\text { Belediyeleri }\end{array}$ & $S_{i}$ & $\boldsymbol{P}_{\boldsymbol{i}}$ & $\boldsymbol{k}_{i a}$ & $\begin{array}{c}\text { Siralama } \\
\left(\boldsymbol{k}_{i a}\right)\end{array}$ & $\boldsymbol{k}_{i b}$ & $\begin{array}{c}\text { Sıralama } \\
\left(\boldsymbol{k}_{\boldsymbol{i} b}\right)\end{array}$ & $\boldsymbol{k}_{i c}$ & $\begin{array}{c}\text { Siralama } \\
\left(\boldsymbol{k}_{i c}\right)\end{array}$ & $\boldsymbol{k}_{i}$ & $\begin{array}{c}\text { Nihai } \\
\text { Siralama }\end{array}$ \\
\hline İstanbul & 0,734 & 11,712 & 0,040 & 3 & 13,146 & 4 & 0,902 & 3 & 5,476 & 4 \\
\hline Ankara & 0,878 & 11,868 & 0,041 & 2 & 14,990 & 2 & 0,923 & 2 & 6,146 & 2 \\
\hline İzmir & 0,925 & 12,878 & 0,044 & 1 & 15,921 & 1 & 1,000 & 1 & 6,546 & 1 \\
\hline Adana & 0,739 & 9,792 & 0,034 & 16 & 12,548 & 9 & 0,763 & 16 & 5,135 & 10 \\
\hline Antalya & 0,696 & 8,840 & 0,031 & 22 & 11,685 & 15 & 0,691 & 22 & 4,764 & 16 \\
\hline Aydın & 0,536 & 7,639 & 0,026 & 27 & 9,279 & 23 & 0,592 & 27 & 3,824 & 25 \\
\hline Balıkesir & 0,657 & 9,721 & 0,033 & 17 & 11,506 & 17 & 0,752 & 17 & 4,758 & 17 \\
\hline Bursa & 0,752 & 10,807 & 0,037 & 9 & 13,058 & 5 & 0,837 & 9 & 5,385 & 6 \\
\hline Denizli & 0,617 & 11,493 & 0,039 & 6 & 11,623 & 16 & 0,877 & 6 & 4,915 & 13 \\
\hline Diyarbakır & 0,336 & 9,180 & 0,031 & 23 & 7,333 & 27 & 0,689 & 23 & 3,221 & 27 \\
\hline Erzurum & 0,652 & 10,632 & 0,036 & 12 & 11,761 & 13 & 0,818 & 12 & 4,909 & 14 \\
\hline Eskişehir & 0,639 & 8,755 & 0,030 & 24 & 10,948 & 19 & 0,681 & 24 & 4,495 & 20 \\
\hline Gaziantep & 0,504 & 8,482 & 0,029 & 25 & 9,182 & 25 & 0,651 & 25 & 3,844 & 24 \\
\hline Hatay & 0,507 & 7,654 & 0,026 & 28 & 8,927 & 26 & 0,591 & 28 & 3,699 & 26 \\
\hline K. Maraş & 0,589 & 10,498 & 0,036 & 15 & 10,931 & 20 & 0,803 & 15 & 4,602 & 19 \\
\hline Kayseri & 0,655 & 10,619 & 0,036 & 13 & 11,787 & 12 & 0,817 & 13 & 4,918 & 12 \\
\hline Kocaeli & 0,650 & 9,681 & 0,033 & 18 & 11,402 & 18 & 0,748 & 18 & 4,718 & 18 \\
\hline Konya & 0,327 & 9,299 & 0,031 & 21 & 7,261 & 28 & 0,697 & 21 & 3,202 & 28 \\
\hline Malatya & 0,555 & 7,795 & 0,027 & 26 & 9,577 & 22 & 0,605 & 26 & 3,941 & 22 \\
\hline Manisa & 0,681 & 11,600 & 0,039 & 5 & 12,450 & 10 & 0,890 & 5 & 5,219 & 9 \\
\hline Mardin & 0,081 & 2,898 & 0,010 & 30 & 2,000 & 30 & 0,216 & 30 & 0,902 & 30 \\
\hline Mersin & 0,812 & 10,848 & 0,037 & 7 & 13,820 & 3 & 0,845 & 7 & 5,660 & 3 \\
\hline Muğla & 0,725 & 11,666 & 0,040 & 4 & 13,020 & 6 & 0,898 & 4 & 5,428 & 5 \\
\hline Ordu & 0,730 & 10,757 & 0,037 & 10 & 12,773 & 8 & 0,832 & 10 & 5,280 & 8 \\
\hline Sakarya & 0,734 & 10,833 & 0,037 & 8 & 12,847 & 7 & 0,838 & 8 & 5,311 & 7 \\
\hline Samsun & 0,565 & 9,528 & 0,032 & 19 & 10,299 & 21 & 0,731 & 19 & 4,313 & 21 \\
\hline ş. Urfa & 0,479 & 9,413 & 0,032 & 20 & 9,193 & 24 & 0,717 & 20 & 3,908 & 23 \\
\hline Tekirdağ & 0,670 & 10,642 & 0,036 & 11 & 11,984 & 11 & 0,820 & 11 & 4,990 & 11 \\
\hline Trabzon & 0,652 & 10,606 & 0,036 & 14 & 11,747 & 14 & 0,816 & 14 & 4,902 & 15 \\
\hline Van & 0,330 & 6,424 & 0,022 & 29 & 6,310 & 29 & 0,489 & 29 & 2,680 & 29 \\
\hline
\end{tabular}

Tablo 3'te sıralamada ilk dört sırayı alan büyükşehirler sırasıyla İzmir, Ankara, Mersin ve İstanbul olmuştur. Türkiye'nin nüfus ve sosyo-ekonomik gelişmişlik göstergeleri (Acar vd., 2019) yönünden ilk sıralarında yer alan bu şehirlerinin büyükşehir web sitelerinde de ilk dört sırada yer alması hizmet edilen vatandaş sayısı, bütçe ve hizmet alanlarıyla ilişkilendirilebilir. Ayrıca, kamu hizmeti sunumu çeşitliliği, donanım ve katılım yönlerinden de söz konusu büyükşehir belediyeleri, diğer büyükşehir belediyelerine göre daha fazla olanaklara sahiptir. Son dört sırada ise güneydoğu, doğu ve iç Anadolu'nun önemli şehirleri arasında yer alan Mardin, Van, Konya ve Diyarbakır bulunmaktadır.

Büyükşehir belediyeleri web sitelerinde yer alan eksiklikler genel olarak göz önüne alındığında; bilgi eksikliği (çeşitli raporlar ve zorunlu resmî belgelerin bulunmaması gibi) yanında şeffaflık, denetim ve hesap verebilirlikle doğrudan ilişkili uygulamaların yeterli düzeyde olmadığı tespit edilmektedir. Web sitelerinde yer alan bu eksiklikler, sunulan 
hizmetler hakkında yeterli bilgilendirme yapılmayarak, vatandaşların yerel yönetimlere ve dolayısıyla kamu kurumlarına güven duymalarını olumsuz yönde etkileyebilecektir.

Büyükşehir belediyelerinin kurumsal web siteleri aracılığıyla vatandaşlara sundukları hizmetler ve ilgili tüm süreçlere ilişkin bilgilendirmeler ile büyükşehir belediye meclisinde katılımcı yaklaşımla alınan kararlar bir yandan şeffaf ve hesap verebilir uygulamaların yürütülmesine öte yandan ise vatandaşların yönetime güven algılarının artmasına yardımcı olacaktır. Dolayısıyla, yerel ve katılımcı demokrasinin gelişmesi, şeffaf ve hesap verebilir bir kamu yönetiminin tesis edilmesi ile vatandaşların kamu kurumlarına güven duymaları arasında doğrudan ve olumlu bir ilişki olduğu anlaşılmaktadır (Gündoğdu ve Aytekin, 2020).

\section{Sonuç}

Büyükşehir belediye yönetimlerini de kapsayarak, yerel yönetimlerin kurumsal web siteleri aracılığıyla, hizmetlerin vatandaş odaklı, katılımcı, etkin ve hızlı bir biçimde açıklık, şeffaflık ve hesap verebilirlik yaklaşımıyla sunulması beklenmektedir.

Yerel yönetimlerin kurumsal web siteleri, yerel yönetim organları ve vatandaşlarla çift yönlü iletişimin artmasına katkı sağlayan önemli bir araç işlevi görmektedir. Bu çalışmada, büyükşehir belediyeleri web siteleri kamusal bilgilere erişim, şeffaflık ve hesap verebilirlik uygulamalarına ilişkin kriterler temel alınarak çözümlenmiştir. Genel bir sonuç olarak, büyükşehir belediyeleri web sitelerinin 5018 sayılı Kanun kapsamında gerekli olan işlemleri yüksek düzeyde gerçekleştirdikleri görülmektedir. Buna karşılık, büyükşehir belediyelerinin web sitelerinde şeffaflık, denetim ve hesap verebilirlikle doğrudan ilişkili birtakım kriterler ise düşük düzeyde yerine getirilmiştir. Kapsam, kullanılan ölçütler ve çözümleme yöntemlerinde farklılıklar olmakla birlikte, bu çalışmada büyükşehir belediyelerinin web sitelerinin şeffaflıkla ilgili yeterlilikleri konusundaki genel değerlendirmeler daha önce bu konuda yapılan ve metin içinde atıf verilen bilimsel çalışmalar ile kısmen benzerlik göstermektedir.

Web sitelerinin yönetimi kurumsal bir yaklaşım olduğundan, farklı yönetimlerin web sitesi politikalarındaki değişiklik, örgütsel değişim, donanım ve öteki olanaklar çerçevesinde belediye başkanları ve yönetimlerinin konuyla ilgili tutumlarını da yansıtmaktadır. Bununla birlikte, yaklaşık 20 yıldır yapılan çalışmalar sonucunda, büyükşehir belediye web sitelerinde denetim ve hesap verebilirlik ile ilgili birtakım kriterlerin genel olarak yeterli düzeyde olmadığı görülmektedir. Bu bağlamda, genel bir öneri olarak aşağıdaki hususları vurgulamak yararlıdır.

Demokratik yönetişim yönünden gelişmiş ülkelerdeki yönetişim ve şeffaflıkla ilgili benzer uygulamalardan yararlanarak, ilgili mevzuat ve önceki bilimsel çalışmalar gözetilerek yerel yönetimlere ilişkin bir yönetişim ve şeffaflık endeksinin oluşturulması ve bu kapsamda, tüm büyükşehir belediyelerinin/belediyelerin bu endekse göre düzenli olarak değerlendirilmesi yararlı olacaktır. Böylece, zaman boyutlu yapılacak karşılaştırmalı çalışmaların, ilerleme ve gerileme durumlarını ve bunların nedenlerini irdelemesi sağlanabilir. Sonuç olarak, açıklık, şeffaflık ve hesap verebilirlik ilkelerinin yerel yönetimler aracılığıyla özendirilmesi kolaylaştırılabilir. 


\section{Kaynakça}

Acar, S.; Bilen-Kazancık, L.; Meydan, M. C.; Işık, M. (2019), illerin ve Bölgelerin Sosyo-Ekonomik Gelişmişlik Sıralaması Araştırması, SEGE-2017. Ankara: T.C. Sanayi ve Teknoloji Bakanlığı Kalkınma Ajansları Genel Müdürlüğü.

Ağmaz, S. (2017), "Türkiye'deki Belediyelerin iç Kontrol Sistemlerinin Etkinliğinin Dış Denetim Bulgularına Göre Analizi”, KÜ. İktisadi ve İdari Bilimler Fakültesi Dergisi, C. 19, S. 4: 74-92.

Aktel, M. (2009), "il Belediye Web Sitelerinin İ̧̧levselliği Üzerine Bir Araştırma”, SDÜ. İktisadi ve İdari Bilimler Fakültesi Dergisi, C. 14, S. 2: 223-240.

Alat, B. (2018), "Türkiye'de II Belediye Web Sitelerinin İşlevselliği Üzerine Bir Araştırma", FÜ. Sosyal Bilimler Dergisi, C. 28, S. 1: 93-114.

Alodalı, F. B.; Tuncer, A.; Usta, S.; Halis, M. (2012), "Yerel Yönetimlerde E-Belediyecilik Uygulamaları: Akdeniz Bölgesi Örneği", Manas Sosyal Araştırmalar Dergisi, C.1, S. 1: 83-95.

Andersen, K. N.; Henriksen, H. Z.; Medaglia, R.; Danziger, J. N.; Sannarnes, M. K.; Enemærke, M. (2010), "Fads and Facts of E-Government: A Review of Impacts of E-Government (2003-2009)", International Journal of Public Administration, Vol. 33, No. 11: 564-579.

Argüden, Y.; Toksöz, F.; Göymen, K.; Kalaycıoğlu, E.; Arıkboğa, E.; Salihoğlu, E.; Öğütücü Şen, F.; İzci, i. (2018), "Vatandaş Bakışıyla" İstanbul İlçelerinin Belediye Yönetişim Karnesi, İstanbul: Argüden Yönetişim Akademisi Yayınları.

Armstrong, C. L. (2011), "Providing a Clearer View: An Examination of Transparency on Local Government Websites", Government Information Quarterly, Vol. 28, No. 1: 11-16.

Arslan, A. (2012). "Türk Belediyelerinde M-Devlet Hizmeti Uygulamaları", Internet Uygulamaları ve Yönetimi Dergisi, C. 3, S. 2: 5-26.

Aytekin, A.; Durucasu, H. (2020), “Çok Kriterli Karar Problemlerine Yönelik Yeni Bir Ölçek: Aralıklı ve Aşamalı Tercih-Önem Ölçeği", (Ed. E. Sarıkaya), Sosyal ve Beşerî Bilimlerde Teori ve Araştırmalar-Cilt 2, Ankara: Gece Kitaplığı: 453-474.

Bertot, J. C.; Jaeger, P. T.; Grimes, J. M. (2012), "Promoting Transparency and Accountability Through Icts, Social Media, and Collaborative E-Government", Transforming Government: People, Process and Policy, Vol. 6, No. 1: 78-91.

Birkinshaw, P. (2006), "Freedom of Information and Openness: Fundamental Human Rights?", Administrative Law Review, Vol. 58, No. 1: 177-218.

Boulianne, S. (2009), "Does Internet Use Affect Engagement? A Meta-Analysis of Research", Political Communication, Vol. 26, No. 2: 193-211.

Cocchia, A. (2014), "Smart and Digital City: A Systematic Literature Review", (Eds. R. P. Dameri, C. Rosenthal-Sabroux), Smart City How to Create Public and Economic Value with High Technology in Urban Space, Cham: Springer: 13-43.

Cuillier, D.; Piotrowski, S. J. (2009), "Internet Information-Seeking and Its Relation to Support for Access to Government Records", Government Information Quarterly, Vol. 26, No. 3: 441-449.

da Cruz, N. F.; Tavares, A. F.; Marques, R. C.; Jorge, S.; de Sousa, L. (2016), "Measuring Local Government Transparency", Public Management Review, Vol. 18, No. 6: 866-893.

Emini, F. T.; Ayaz, Ç. E. (2018), "Türkiye'de Bilgi Edinme Hakkı: Büyükşehir Belediye Web Sayfaları Üzerinden Bir Değerlendirme", Journal of Awareness, C. 3, S. 1: 13-26.

Erarslan-Yayınoğlu, P.; Sayımer, I.; Arda, Z. (2007), "Belediyelerin Kurumsal Web Sitesi Kullanımı Üzerine Bir İnceleme: Londra Büyükşehir Yönetimi ve İstanbul Büyükşehir Belediyesi Web Sitesi Ana Sayfalarının Karşılaştırılması", Galatasaray Üniversitesi Iletişim Dergisi, S. 7: 129-157. 
European Commission (2020), "eGovernment Benchmark 2020: eGovernment That Works for the People", https://digital-strategy.ec.europa.eu/en/library/egovernment-benchmark-2020-egovernmentworks-people, (Erişim: 05.05.2021).

Gandía, J. L.; Archidona, M. C. (2008), "Determinants of Web Site Information by Spanish City Councils", Online Information Review. Vol. 32, No. 1: 35-57.

Garrido-Rodríguez, J. C.; López-Hernández, A. M.; Zafra-Gómez, J. L. (2019). "The Impact of Explanatory Factors on a Bidimensional Model of Transparency in Spanish Local Government". Government Information Quarterly, Vol. 36, No. 1: 154-165.

Genç, A. (2019), "Türkiye ile Avrupa Birliği'nin E-Devlet Politikalarının Karşılaştırılması”, AB Uzmanlığı Tezi, T.C. Ulaştırma ve Altyapı Bakanlı̆̆ı, https://www.uab.gov.tr/uploads/pages/kutuphane/aykut-genctez.pdf, (Erişim: 05.05.2021).

Gündoğdu, H. G. (2018), "Yerel Yönetimlerde Çalışanların E-Demokrasi ve E-Katılım Algısına İlişkin Bir Araştırma: Konya Büyükşehir Belediyesi Örneği", Dumlupınar Üniversitesi Sosyal Bilimler Enstitüsü Dergisi, C. 55, S. 1: 1-16.

Gündoğdu, H. G. (2020), Türkiye'de Kamu Yönetiminde Koordinasyon, Ankara: Nobel Bilimsel Eserler.

Gündoğdu, H. G.; Aytekin, A. (2020), "Vatandaşların Kamu Yönetimine Güveni: Ampirik Bir Araştırma", (Ed. M. Mete), iktisadi ve İdari Bilimlerde Teori ve Araştırmalar II-Cilt 1, Ankara: Gece Kitaplığı: 297-338.

Harrison, T.M.; Sayogo, D.S. (2014), "Transparency, Participation, and Accountability Practices in Open Government: A Comparative Study", Government Information Quarterly, Vol. 31, No. 4: 513-525.

Heald, D. (2003), "Fiscal Transparency: Concepts, Measurement and UK Practice", Public Administration, Vol. 81, No. 4: 723-759.

Hirsch, W. Z.; Osborne, E. (2000), "Privatization of government services: Pressure-group resistance and service Transparency", Journal of Labor Research, No. 21: 315-326.

Holzer, M.; Kim, S-T. (2005), Digital Governance in Municipalities Worldwide: A Longitudinal Assessment of Municipal Websites Throughout the World, New Jersey: APSA.

Holzer, M.; Manoharan, A. P. (2016), Digital Governance in Municipalities Worldwide (2015-16), New Jersey: Rutgers University.

Jaeger, P. T.; Bertot, J. C. (2010), "Transparency and Technological Change: Ensuring Equal and Sustained Public Access to Government Information", Government Information Quarterly, Vol. 27, No. 4: 371-376.

Karakaya-Polat, R. (2006), E-Belediyecilik Kılavuzu Yerel Yönetim Vatandaş Etkileşimi, İstanbul: Tasam Yayınları.

Karakurt-Tosun, E. (2008), “Türkiye'de E-Belediyecilik Uygulamaları: Bursa Nilüfer-OsmangaziYıldırım Belediyelerinin Web Sitelerinin Analizi", Çağdaş Yerel Yönetimler Dergisi, C. 17, S. 2: 71-94.

Karkin, N.; Janssen, M. (2014). "Evaluating websites from a public value perspective: A review of Turkish local government websites". International Journal of Information Management, Vol. 34, No. 3: 351-363.

Keleş, R. (2019), Yerinden Yönetim ve Siyaset, İstanbul: Cem Yayınevi.

Kerman, U.; Altan, Y.; Aktel, M.; Özaltın, O. (2012). "Türkiye'de E-Devlet: İl Düzeyinde Bir Analiz”. Sosyoekonomi, C. 18, S. 18: 45-80.

Kosovo Democratic Institute; NGO AKTIV (2020), "2019 Municipal Transparency and Accountability Index", http://www.ngoaktiv.org/uploads/files/Municipal-Transparency-2019-ENG, (Erişim: 25.12.2020). 
Lindquist, E. A.; Huse, I. (2017), “Accountability and Monitoring Government in the Digital Era: Promise, Realism and Research for Digital-Era Governance", Canadian Public Administration, Vol. 60, No. 4: 627-656.

Liu, S. M.; Yuan, Q. (2015), "The Evolution of Information and Communication Technology in Public Administration", Public Administration and Development, Vol. 35, No. 2: 140-151.

Lupu, D.; Lazăr, C.G. (2015), "Influence of E-Government on the Level of Corruption in Some EU and Non-EU States", Procedia Economics and Finance, No. 20: 365-371.

Mecek, M. (2017), “E-Devlet ve E-Belediye: Kavramsal Çerçeve ve Türkiye'de Belediye Web Sitelerine Yönelik Yapılan Çalışmaların İncelenmesi”. SDÜ. İktisadi ve İdari Bilimler Fakültesi Dergisi, C. 22, Kayfor 15 Özel Sayısı: 1815-1851.

Moon, M. J. (2002), "The Evolution of E-Government among Municipalities: Rhetoric or Reality?", Public Administration Review, Vol. 62, No. 4: 424-433.

Moon, M. J. (2003), “Can IT Help Government to Restore Public Trust?: Declining Public Trust and Potential Prospects of IT in the Public Sector", Paper presented at the 36th Hawaii International Conference on System Sciences (HICSS'03, Hawaii, 6-9 January).

Navarro-Heras, E.; Mora-Agudo, L.; Delgado-Jalón, M. L. (2016), “Analyzing the Transparency Traditional Variables within the Spanish Municipalities", Transylvanian Review of Administrative Sciences, No. 47(E): 129-145.

Negiz, N.; Saraçbaşı, Y. (2012), “Demokratik Yönetişim Sağlanmasında E-Belediye ve Uygulamaları: Akdeniz Bölgesi Örneği”, Bilgi Ekonomisi ve Yönetimi Dergisi, C. 7, S. 1: 42-52.

Obi, T. (2018), "The 14th Waseda - IAC International Digital Government Rankings 2018 Report", https://idg-waseda.jp/pdf/The_2018_Waseda-IAC_Digital_Government_Rankings_Report.pdf, (Erişim: 21.03.2021).

Parlak, B.; Sobacı, M. Z. (2008)," Türkiye'deki Büyükşehir Belediyelerinin Website Temelli Hizmetleri: Karşılaştırmalı Bir İşlevsellik Analizi”, (Ed. B. Parlak), Kamu Yönetiminde Yeni Vizyonlar, Ankara: Turhan Kitabevi: 229-257.

Pina V.; Torres, L.; Royo, S. (2007), "Are ICTs Improving Transparency and Accountability in the EU Regional and Local Governments? An Empirical Study", Public Administration, Vol. 85, No. 2: 449-472.

Piotrowski S.J.; Borry, E. L. (2009), "Transparency and Local Government Websites", Handbook of Research on Strategies for Local E-Government Adoption and Implementation: Comparative Studies, (Ed. C.G. Reddick), IGI Global: Hershey, PA, USA: 390-407.

Piotrowski, S. J.; Van Ryzin, G. G. (2007), "Citizen Attitudes Toward Transparency in Local Government", American Review of Public Administration, Vol. 37, No. 3: 306-323.

Quinn, A. C. (2003), "Keeping the citizenry informed: Early congressional printing and 21st century information policy", Government Information Quarterly, Vol. 20, No. 3: 281-293.

Rebolledo, M.; Zamora-Medina, R.; Virgili, J. R. (2017), "Transparency in citizen participation tools and public information: A comparative study of the Spanish city councils' websites", El profesional de la información, Vol. 26, No. 3: 361-369.

Roberts, A. (2006), Blacked Out: Government Secrecy in the Information Age, Cambridge: Cambridge University Press.

Ruano de La Fuente, J. M. (2014), "E-Government Strategies in Spanish Local Governments", Local Government Studies, Vol. 40, No. 4: 600-620.

Sayımer, İ., Dondurucu, Z.; Küçüksaraç, B. (2019), “Dijitalleşen Kentlerde Yönetişim: Marmara Bölgesi Büyükşehir Belediyeleri'nin Karşılaştırmalı E-Belediyecilik Uygulamaları”, IBAD Sosyal Bilimler Dergisi, C. 5, S. Güz: 420-443. 
Sobacı, M. Z.; Altınok, R. (2011). "Türkiye'de Büyükşehir Belediyelerinin E-Katılım Uygulamaları: Website İçerik Analizi", VIII. Kamu Yönetimi Forumu: Kamu Yönetimi ve Teknoloji, Ankara: TODAIE Yayınları: 786-803.

Stasavage, D. (2003), "Transparency, Democratic Accountability, and the Economic Consequences of Monetary Institutions", American Journal of Political Science, Vol. 47, No. 3: 389-402.

Şahin, A. (2019), Türk Kamu Yönetiminde Yapısal Dönüşüm ve E-Devlet, İstanbul: Atlas Akademi.

Şat, N. (2016), "Türkiye'de Büyükşehir Belediyelerinin Genel Ağ (Web) Sitelerinin Analizi”, Türk İdare Dergisi, C. 482, S. 1: 183-237.

Tasan-Kok, T.; Vranken, J. (2011), Handbook for Multilevel Urban Governance in Europe: Analysing Participatory Instruments for an Integrated Development, The Hague: European Urban Knowledge Network.

T.C. Başbakanlık (2003), Kamu Yönetiminde Yeniden Yapılanma: Değişimin Yönetimi İçin Yönetimde Değişim, Ankara: T.C. Başbakanlık.

T.C. Kalkınma Bakanlığı (2018), e-Devlet Hizmetlerinin Geliştirilmesi Çalışma Grubu Raporu, Ankara: T.C. Kalkınma Bakanlı̆̆ı.

T.C. Sayıştay (2006), e-Devlete Geçişte Kamu Kurumları Internet Siteleri Performans Denetimi Raporu, Ankara: T.C. Sayıştay Başkanlığı.

Transparency International (2015), Local Governance Integrity: Principles and Standards, Berlin: Transparency International.

Twizeyimana, J. D.; Andersson, A. (2019), "The public value of E-Government -A literature review", Government Information Quarterly, Vol. 36, No. 2: 167-178.

UN (2020), “E-Government Survey 2020", New York: United Nations, https://publicadministration.un.org/egovkb/Portals/egovkb/Documents/un/2020-

Survey/2020\%20UN\%20E-Government\%20Survey\%20(Full\%20Report).pdf (Erişim: 19.02.2021).

Uzunali, E.; Görmez, A. H. (2019), “Türkiye'de Büyükşehir Belediyelerinin Mali Yapıları ve Bütçe Sürdürülebilirliklerinin Oran Analiz Yöntemiyle Karşılaştırılması", International Journal of Economic and Administrative Studies, S. 25: 95-118.

Vidali, J. J.; Holeway, R. E. (1975), "Stapel scales versus semantic differential scales: Further evidence". Psychological Reports, Vol. 36, No. 1: 165-166.

Welch, E. W.; Hinnant, C. C.; Moon, J. M. (2005), “Linking Citizen Satisfaction with E-Government and Trust in Government", Journal of Public Administration Research and Theory, Vol. 15, No. 3: 371-391.

Yazdani, M.; Zarate, P; Zavadskas, E. K.; Turskis, Z. (2019), “A Combined Compromise Solution (CoCoSo) method for multi-criteria decision-making problems". Management Decision, Vol. 57, No. 9: 2501-2519.

Yıldız, M. (1999), “Yerel Yönetimlerde Yeni Bir Katılım Kanalı, İnternet: Türkiye ve ABD’de Elektronik Kamu Bilgi Ağları", Çağdaş Yerel Yönetimler Dergisi, C. 8, S. 4: 144-156.

Žižović, M.; Pamucar, D. (2019), "New model for determining criteria weights: Level Based Weight Assessment (LBWA) model", Decision Making: Applications in Management and Engineering, Vol. 2, No. 2: 126-137. 


\section{Extended Summary}

\section{Evaluation of Metropolitan Municipalities Web Sites in terms of Governance Principles}

The acceleration of developments in Information and Communications Technology (ICT) and understanding of egovernment has contributed to the application of democratic governance on the internet environment. In this respect, public institutions have the opportunity to increase transparency, accountability, trust, and participation by providing their services to citizens through ICT. Moreover, the websites of public agencies have an important role in the provision of public services, and the relations between citizens and central and especially local governments. In terms of implementation of governance principles, local governments publicize information such as the agenda of local councils, minutes of council meetings, their annual budgets, the strategic plans, and the other essential documents on their official websites. Within the scope of this study, the official websites of local governments, which are the closest service units to the citizens, are assessed in terms of governance principles such as openness, transparency, and participation.

As a result of the increasingly efficient use of ICTs in management systems, increased access to information has increased the need for transparency of management. Practices based on "good governance" come to the fore, depending on the understanding of openness and transparency (Birkinshaw, 2006, Hirsch \& Osborne, 2000) and accountability, which are the preconditions of a democratic society. The widespread use of ICTs in management procedures has made administrative data more accessible to people. Transparency, integrity, and accountability in management are also emphasized as prerequisites (Transparency International, 2015), and reducing corruption increases trust in management (Stasavage, 2003; Pina et al., 2007). Metropolitan municipal administrations play an important role in carrying out planned and scheduled events that benefit people residing within metropolitan municipalities' boundaries. In this context, it is expected that services will be provided in a citizen-oriented, participatory, effective, and timely manner through official websites in local governments, with an emphasis on openness, transparency, and accountability. It is important that metropolitan municipalities pay more attention to and improve the governance processes on their websites. It will be possible to contribute to the increase of trust in public administration by increasing practices focused on the governance approach in the services provided by metropolitan municipalities to citizens through their websites. This study aims to examine the degree to which metropolitan municipalities follow governance standards such as access to public information, transparency, and accountability. In this regard, the study offers a literature-based appraisal as well as a current contribution to the field. Also, the study's unique feature is the creation of data through content analysis and the application of multi-criteria decisionmaking (MCDM) methods. In this context, the Stapel scale was used to evaluate metropolitan municipalities according to governance criteria. The level of participation in the statement in the middle of the Stapel Scale is determined by five or three degrees below and above (or to the right and left) of this statement. In this study, the \pm 3 value and the "satisfactory" term were used. In the MCDM model, LBWA (Level Based Weight Assessment) was used to determine the weights of the criteria. LBWA was chosen to ensure that criteria that are close to each other are weighted effectively. Also, CoCoSo (Combined Compromise Solution) method was used to rank metropolitan websites in terms of governance principles. CoCoSo provides an integrated solution using WSM, WPM, and the gray relational coefficient. Considering the analysis results, the following observations are made for metropolitan municipalities. According to the findings, Izmir, Ankara, Mersin, Istanbul, and Mugla ranked first through fifth in terms of metropolitan municipal website governance quality. These cities have more opportunities in terms of population and socio-economic development indicators of Turkey (Acar et al., 2019). Besides, these cities are at the forefront in line with the number of citizens served, budget, and service areas. The last five ranks are Mardin, Van, Konya, Diyarbakır and Hatay. The major deficiencies found on the websites of metropolitan municipalities within the scope of the study can be summarized as follows. Basically, the metropolitan municipalities have typically ensured that their websites meet the legal requirements. In addition to insufficient information provided by the web pages, the procedures specifically related to transparency, audit, and accountability are not up to standards. Besides, deficiencies are evident in some criteria related to governance. These shortcomings on the websites may negatively affect the citizens' trust in local governments and therefore in public agencies. These findings are partially similar to previous studies (Parlak \& Sobacı, 2008; Kerman et al., 2012; Karkin \& Janssen, 2014; Şat, 2016; Emini \& Ayaz, 2018; Sayımer et al., 2019). Certain auditing and transparency standards in metropolitan municipality websites are typically not at a satisfactory level, according to studies conducted over the last 20 years. In this context, it is useful to highlight the following points as a general recommendation. It is critical that local government audit units carry out their duties independently and impartially to activate governance in local governments. Moreover, it is important for transparency that they make the reviews and reports that will be produced as a result of the audit available to the public via their websites. Reviewing and improving the web content of the local government administrations will contribute to increasing the service quality offered to citizens and ensuring user satisfaction. Finally, a governance and accountability index for local governments should be created, taking into account applicable legislation and previous scientific studies, and all municipalities should be evaluated regularly by using this index. 